\title{
Agrobacterium may be used as a suitable experimental system for genetic analysis of resistance to (at least Xenorhabdus budapestensis) antimicrobial peptide complexes
}

\author{
András Fodor ${ }^{\text {Corresp.. }}$ 1,2 ， László Makrai ${ }^{3}$ ， Dávid Vozik ${ }^{4}$ ， Ferenc Olasz ${ }^{5}$ ， János Kiss ${ }^{6}$, Michael Gardner Klein ${ }^{7}$, \\ Muhamad-Akbar Bin-Abdul Ghaffar ${ }^{8}$, László Szabados ${ }^{9}$, Ahmed Nour El-Deen ${ }^{10}$, László Fodor ${ }^{3}$, Erzsébet \\ Burgetti Böszörményi ${ }^{11}$, Katalin Bélafi-Bakó ${ }^{12}$, Steven A. Forst ${ }^{13}$ \\ 1 Department of Genetics, József Attila University of Szeged, Szeged, Hungary \\ 2 Department of Genetics, József Attila University Szeged, Szeged, Hungary \\ 3 Department of Microbiology and Infectious Diseases, University of Veterinary Medicine, Budapest, H-1581 Budapest P.O.Box 22, Hungary \\ 4 Research Institute on Bioengineering, Membrane Technology and Energetics, University of Pannonia, Egyetem utca 10, H-8200 Veszprém, Hungary \\ ${ }^{5}$ Agricultural Biotechnology Institute, National Agricultural Research and Innovation Centre (NARIC), Szent-Györgyi Albert utca 4, H 2101 Gödöllö, \\ Hungary \\ 6 Agricultural Biotechnology Institute, National Agricultural Research and Innovation Centre (NARIC), Gödöllő, Hungary \\ 7 Department of Entomology, Ohio State University, Madison Ave., Wooster OH 44691 USA, Ohio, United States \\ 8 Department of Horticulture and Crop Science, Ohio State University, Madison Avenue, Wooster,OH 44691, Ohio, United States \\ 9 Biological Research Center, Hungarian Academy of Sciences, Szeged, Hungary \\ 10 Agricultural Zoology Department, / Faculty of Agriculture, Mansoura University,, Mansura, Egypt \\ 11 Department of Epidemiology / Faculty of Health Sciences, Semmelweis University of Medical Sciences, Budapest, Hungary \\ 12 Research Institute on Bioengineering, Membrane Technology and Energetics, University of Pannonia, Egyetem utca 10, Veszprém, H-8200, Hungary \\ 13 Department of Biology,, University of Wisconsin-Milwaukee, Milwaukee, Wisconsin, USA \\ Corresponding Author: András Fodor \\ Email address: fodorandras@yahoo.com
}

Background Antimicrobial compounds released by the entomopathogenic nematode-symbiont bacterium Xenorhabdus budapestensis (EMA) are oligopeptides and the "trump" is fabclavine. They kill antibiotic multi-resistant Escherichia coli, Salmonella; mastitis-isolate Staphylococcus aureus, E. coli and Klebisella pneumoniae; S. aureus MRSA strain; plant-pathogenic Erwinia amylovora; Xanthomonas, Clavibacter, and Pseudomonas strains. Each tested Phytophthora isolate proved also sensitive. Fabclavine was claimed toxic, however, Proteus, some Pseudomonas and Agrobacterium strains are resistant. Our goal is to establish a suitable system for genetic analysis of antimicrobial peptide (AMP)resistance by beneficially using the experimental toolkit of Agrobacterium research.

Methods. We tested the anti-Agrobacterium activity of the native cell-free culture media (CFCM) of EMA by agar diffusion assay. EMA_PF2 peptide fraction (of reproducible HPLC and MALDI profile) was then isolated from CFCM of EMA and exerted strong AMP activity on both Gram-negative and positive targets. The sensitive/resistant (S/R) phenotype of Agrobacterium strains of known genotype to EMA_PF2 was determined in liquid culture bio-assays. We tested 1 wild-type (A281) and 3 T-DNA-deleted (AGL1, EHA105, A4T) agropine (L, L,-succinamopine, AGR) catabolizing strains with C58 chromosome and of pTiBo542 plasmid; 5 pTi58-plasmid-cured (HP1836, HP1840, HP1841, HP1842, HP1843) and 1 T-DNA deleted and binary vector harboring (SZL4) nopaline-catabolizing strains of C58 chromosome; and 2 TDNA deleted octopine-catabolizing (OCT) strains with and without binary vector of Ach5 chromosome (SZL2 and HP 1837, respectively).

Results. Agrobacterium tumefaciens A281, HP1836, HP1840, HP1841, HP1842, HP1843, SZL4 and SZL2 
proved resistant; HP1837, AGL1, EHA105 and A4T strains were sensitive to EMA PF2. All but SZL4 showed the same S/R phenotype to CFCM and EMA_PF2.

Discussion. There are both sensitive and resistant strains of C58 and Ach5 chromosome and of different opine type strains. All but one T-DNA(-) strains (SZL2) were sensitive to EMA PF2. All plasmid-cured strains and the wild-type A281 were resistant.

Conclusions. We consider EMA_PF2 as a natural complex of interacting AMP molecules and identified resistant (R) and sensitive (S) Agrobacterium strains to it. The S/R phenotype seems independent on both the chromosome and the opine-type. Each tested T-DNA-Deleted pTiBo542 harboring strain proved sensitive while that of harboring intact plasmid was fully resistant. The availabilities of the T-DNA-Deleted EMA_PF2 (S) and the of the T-DNA-Non-Delated EMA_PF2 (R) pTiBo542 plasmid harboring Agrobacterium strains may provide a suitable system for genetic (complementation) analysis for resistance mechanisms towards EMA_PF2 and maybe towards other AMPs active on Gram-negatives. The main argument is the exceptional unique opportunity for applying the genuine tools binary vector strategy. 
Agrobacterium: a suitable experimental system for genetic analysis of resistance to (at least Xenorhabdus budapestensis) antimicrobial peptide complexes

András Fodor Corresp., 1 , László Makrai ${ }^{2}$, Dávid Vozik ${ }^{3}$, Ferenc Olasz ${ }^{4}$, János Kiss ${ }^{5}$, Michael Gardner Klein ${ }^{6}$, Muhamad-Akbar Bin-Abdul Ghaffar ${ }^{7}$, László Szabados ${ }^{8}$, Ahmed Nour El-

Deen ${ }^{9}$, László Fodor ${ }^{2}$, Erzsébet Burgetti Böszörményi ${ }^{10}$, Katalin Bélafi-Bakó ${ }^{11}$, Steven A. Forst 12

${ }^{1}$ Department of Genetics, József Attila University of Szeged, Középfasor 52, H-6726 Szeged,

8 Hungary

$9{ }^{2}$ Department of Microbiology and Infectious Diseases, University of Veterinary Medicine, Budapest, H-1581 Budapest P. O. Box 22, Hungary

${ }^{3}$ Research Institute on Bioengineering, Membrane Technology and Energetics, University of

Pannonia, Egyetem utca 10, H-8200 Veszprém, Hungary

${ }^{4}$ Agricultural Biotechnology Institute, National Agricultural Research and Innovation Centre (NARIC), Szent-Györgyi Albert utca 4, H 2101 Gödöllö, Hungary

${ }^{5}$ Agricultural Biotechnology Institute, National Agricultural Research and Innovation Centre (NARIC), Gödöllö, Hungary

${ }^{6}$ Department of Entomology, Ohio State University, Madison Ave., Wooster OH 44691 USA, Ohio, United States

${ }^{7}$ Department of Horticulture and Crop Science, Ohio State University, Madison Avenue, Wooster, OH 44691, Ohio, United States

${ }^{8}$ Biological Research Center, Hungarian Academy of Sciences, Szeged, Hungary

${ }^{9}$ Agricultural Zoology Department, / Faculty of Agriculture, Mansoura University, Mansura, Egypt

${ }^{10}$ Department of Epidemiology / Faculty of Health Sciences, Semmelweis University of Medical Sciences, Budapest, Hungary

${ }^{11}$ Research Institute on Bioengineering, Membrane Technology and Energetics, University of Pannonia, Egyetem utca 10, Veszprém, H-8200, Hungary

${ }^{12}$ Department of Biology, University of Wisconsin-Milwaukee, Milwaukee, Wisconsin, USA 
ABSTRACT

Background: Antimicrobial compounds released by Xenorhabdus budapestensis (EMA) are oligopeptides. The "trump" is the fabclavine. They kill S. aureus MRSA; antibiotic multiresistant Escherichia coli, Salmonella; mastitis-isolate Staphylococcus aureus, E. coli and Klebisella pneumoniae; Erwinia amylovora; Xanthomonas, Clavibacter, and several Pseudomonas strains. Each Phytophthora proved also sensitive. Fabclavine was claimed toxic, however, some Proteus, Pseudomonas and Agrobacterium strains are resistant. Our goal is to establish a suitable system for genetic analysis of antimicrobial peptide (AMP)-resistance by beneficially using the experimental toolkit of Agrobacterium research.

Methods: We tested the anti-Agrobacterium activity of the native cell-free culture media (CFCM) of EMA by agar - diffusion assay. EMA_PF2 peptide fraction (of reproducible HPLC and MALDI profile) was isolated from CFCM of EMA. It exerted strong AMP activity on both Gram-negative and positive targets. The sensitive/resistant (S/R) phenotype of Agrobacterium strains of known genotype to EMA_PF2 was determined in liquid culture bioassays. We tested wild-type (A281) and T-DNA-deleted ( $\triangle$-TDNA, AGL1, EHA105, A4T) agropine (L, L,-succinamopine, AGR) catabolizing strains with C58 chromosome and of pTiBo542 plasmid; 5 pTi58-plasmid-cured (HP1836, HP1840, HP1841, HP1842, HP1843) and 1 T-DNA deleted and binary vector harboring (SZL4) nopaline-catabolizing strains of C58 chromosome; and 2 T-DNA deleted octopine-catabolizing (OCT) strains with and without binary vector of Ach5 chromosome (SZL2 and HP 1837, respectively).

Results: Agrobacterium tumefaciensA281, HP1836, HP1840, HP1841, HP1842, HP1843, SZL4 and SZL2 proved resistant; HP1837, AGL1, EHA105 and A4T strains were sensitive to EMA PF2. All but SZL4 showed the same S/R phenotype to CFCM and EMA_PF2.

Discussion: There are both sensitive and resistant strains of C58 and Ach5 chromosome and of different opine type strains. All but one $\Delta$-TDNA strains (SZL2) were sensitive to EMA PF2. All plasmid-cured strains and the wild-type A281 were resistant.

Conclusions: We consider EMA_PF2 as a natural complex of interacting AMP molecules and 9 identified resistant (R) and sensitive (S) Agrobacterium strains to it. The S/R phenotype seems 60 independent on both the chromosome and the opine-type. Each tested T-DNA-Deleted pTiBo542 1 harboring strain proved sensitive while that of harboring intact plasmid was fully resistant. The 2 availabilities of the $\triangle$-TDNA, EMA_PF2 (S) and the of the T-DNA-Non-Delated EMA_PF2 3 (R) pTiBo542 plasmid harboring Agrobacterium strains may provide a system for genetic 64 (complementation) analysis for resistance mechanisms towards EMA_PF2 and maybe towards 
65 other AMPs active on Gram-negatives. The main argument is the exceptional unique opportunity 66 for applying the genuine tools binary vector strategy.

67 Key words: Agrobacterium; Ti plasmid; Intact/Cured/T-DNA Deleted; Sensitive/Resistant 68 to; Xenorhabdus budapestensis / EMA; Antimicrobial peptides /AMP; EMA_PF2 


\section{INTRODUCTION}

The emergence of antibiotic multi-resistance in pathogenic bacteria has become alarming in the recent decades, all over the world; invoking an enormous public concern, not only from human humanclinical,

The number of pathogenic bacterium species of clinical, (Talbot et al.,2006; Talbot, 2008; Dötsch et al., 2009; Cantas et al, 2013; Exner et al., 2017); veterinary (Gebreyes and Thakur 2005; Endimiani et al., 2011; Szmolka \& Nagy, 2013; Moore et al., 2013; Davis et al., 2013; McManus et al, 2015; Rzewuska et al., 2015; Marques et al., 2016); and plant medical (Zatuga et al., 2014; Li, Plésiat and Nikaido, 2015; Fodor et al., 2012; Fodor at al., 2017) aspects has dangerously been increasing. Those bacterium species which have been put in the ESKAPE (based on the initials of respective genus name) list (Rice, 2008) are: Enterococcus faecium, (Williamson et al., 1983; Sun et al., 2012; Gilmore, Lebreton, \& van Schaik, W. 2013; Miller, Munita \&Arias, 2014) Staphylococcus aureus, (MRSA) [41] (Tomasz, 1998; Tenover et al., 2008; Ellington et al, 2010; Shi et al., 2014); Klebsiella pneumoniae, (Schechner et al., 2008; Schwaber et al., 2011); Acinetobacter baumannii, (Vila, Martí, and Sanchez-Céspedes, 2007; Antunes, Visca and Towner 2014); Lee et al., 2017); Pseudomonas aeruginosa, (Nordman et al., 1993; Strateva and Yordanov, 2009; Hirata et al, 2002; Nehme and Poole, 2008; Mulcahy et al, 2010, 2014; Gonçalves-deAlbuquerquea, 2015; Jeukens et al., 2017) and Enterobacter (Rice, 2008) species. To overcome extended-spectrum beta-lactamase (ESBL)-caused resistance problems (Pitout, 2008) carbapenem antibiotics (Papp-Wallace et al., 2011) were developed, but carbapenem- resistant (CRE) Enterobacteriaceae (Temkin et al., 2014); and Klebsiella (Gupta et al., 2011) appeared soon. Lately, the rediscovered and rehabilitated colistin was considered as a final trump (Kádár et al., 2013) until colistin resistance was found in Gram-negative bacterium species, (Otter et al., 2017). Antibiotics are also used in plant medicine (Mc Manus et al., 2002; Stockwell, Sundin and Jones, 2002; Aćimović et al., 2015), but the increasing number of streptomycin-resistant Erwinia amylovora isolates has been causing serious problems both in the USA (Förster et al., 2015) and in Europe (Gusberti et al., 2015).

Environmentally-friendly plant, - veterinary, - and human antibiotics of novel modes of action are imperatively needed. Antimicrobial peptides (AMP) have been hoped to provide perspectives. AMPs have found in practically all known prokaryotic a eukaryotic organisms (Jenssen, 2006; Ötvös and Wade, 2014; Mojsoska \& Jenssen, 2015). AMPs are mostly of broad target spectra and of strong antibiotic activity. The patented AMPs have recently been listed, (Kosikowska and Lesner, 2016) http://dx.doi.org/10.1080/13543776.2016.1176149, but relatively few of them is in use.

The options of finding novel natural has recently been revolutionized by tools provided by bioinformatics, allowing curation and comparative analysis of genomic and bioinformatics metabolic data of potential antibiotic producing organisms (Vallenet et al., 2013); especially since the discovery of the "On-Demand Production" of bioactive natural products, (Bode et al., 2015). The symbiotic bacterial partners of the entomopathogenic nematode / bacteria (EPN/EPB) associations (Steinernema / Xenorhabdus and Heterorhabditis / Photorhabdus) produce antimicrobials (Akhurst, 1982; Forst \& Nealson, 1996) mainly AMPs (Vivas \& Goodrich-Blair, 2001); (Bode, 2009). Their natural role of this antimicrobial compounds is to provide monoxenic 
conditions for the respective EPN/ EPB) complex in polyxenic (insect cadaver; soil) environmental conditions. All known EPB-produced AMP compounds are non-ribosomal peptides (NRP), which means that they are synthetized enzymatically by multi-enzyme thiotemplate mechanisms using non-ribosomal peptide synthetases (NRPS), fatty acid synthase (FAS)-related polyketide synthases (PKS), or a hybrid biosynthesis thereof (Reimer \& Bode 2014). Some examples are xenocoumacins (Park et al., 2009); a novel new lysine-rich cyclolipopeptide family (Gualtieri et al., 2009) from Xenorhabdus nematophila; and the cabanilasin from X. cabanillasii (Houard et al., 2013).

Our team identified novel some Xenorhabdus species (Lengyel et al., 2005). Two of them, $X$. budapestensis (EMA) and X. szentirmaii (EMC), bacterial symbionts of the nematodes Steinernema bicornutum and $S$. rarum, respectively, have been proven exceptionally great antibiotic producers (Furgani et al., 2008); Böszörményi et al., 2009; Vozik et al., 2015). The cell-free culture media (CFCM) of X. budapestensis (EMA) exerted a strong antimicrobial effects in different bioassays on antibiotic multiresistant laboratory strains, zoonic, veterinary and clinical isolates of S. aureus, E. coli, Klebsiella, (Furgani et al., 2008); and Salmonella, (in preparation); several Clavibacter, Xanthomonas, isolates Phytophthora species, phytopathogenic Pseudomonas, (Fodor et al., 2012) as well as_in E. amylovora rifampicin and kanamycin resistant strains both in vivo and in planta, (Vozik et al., 2015) and on Leishmania donovani isolate (Fodor, Kulkarni \& McGwire, unpublished).

Fellow scientists in other laboratories confirmed our findings. Not only X. budapestensis, (Fuchs et al., 2012) but also $X$. szentirmaii is a source of antimicrobial compounds of great potential, (Gualtieri et al. 2014). Szentiamide, proved a powerful anti-Plasmodium molecule, (Nollmann et al. 2012). A respected French team sequenced our EMC strain (Gualtieri et al., 2014). Our data on EMA and EMC (Lengyel et al., 2005; Furgani et al, 2008; Böszörményi et al, 2009) were carefully re-evaluated by Bode and his associates. They sequenced EMA, but they did not make it publicly available. They discovered that the most powerful antimicrobial non-ribosomal peptide (NRP) compound is fabclavine, which is present in isomeric forms both in EMA and EMC (Fuchs et al, 2012). Comparative genome-analysis identified the hybrid NRPS-PKS gene cluster of $61 \mathrm{~kb}$ in both EMA and EMC that is responsible for coding enzyme activities acting in the fabclavine biosynthetic pathway. However, Bicornutin A, erroneously proposed previously as being the active potent antibiotics of EMA by us, does not have any antimicrobial potential (Fuchs et al., 2012; Fuchs et al., 2014); although it is usually present in antimicrobially active peptide preparations. The fabclavines are structurally similar to cationic antimicrobial peptides (Lin et al., 2013), which are "displaying pronounced synergistic effects in combination with other antibiotics. This could even increase their bioactivity in vivo in combination" (Fuchs et al., 2014) with other AMP molecules produced by $X$. budapestensis.

Despite the fact that the most active antimicrobial component (the fabclavine) produced by $X$. budapestensis (EMA) has been discovered and condemned as being generally toxic, the "EMA story" may not necessarily be terminated, since we found resistant organisms in nature the nature; demonstrating that it the EMA AMPs are not an overall ("sulfuric-acid-like") poisons. 
Either this is the case or not, the antimicrobially extreme strong EMA-AMP complex seems to be useful model for studying resistance problems related to peptide-type antimicrobial in the nature.

At this point we have become focusing on the resistance / sensitivity problems rather than to the options of the immediate application. Considering that there seems to be more realistic to working on developing the natural complex of interacting natural released by EMA to an agriculturally applicable bio-product (such as compost component) rather than developing on fabclavine with the aim of by disarming this toxic molecule either by chemical or biological (posttranslational mutagenesis, for instance, Wright et al., 2016) we worked with a well reproducible peptide isolate, EMA_PF2 and tested in the soil-born plant pathogenic bacterium, Agrobacterium. We previously worked on Agrobacterium as a plant pathogenic target (Fodor et al., 2012) and found Agrobacterium strains of different S/R phenotypes to cell-free culture media of EMA and EMC in both overlay and agar-diffusion tests. We decided to try to benefit from the sophisticated genetic toolkit established by fellow researchers on A. tumefaciens as number 1 tool of molecular plant biotechnology, (recently reviewed by Nester, 2015).

The aim of this study is to develop an amenable experimental system for studying resistance mechanisms toward natural individual and complex antimicrobial peptides in the future. The advantages of Agrobacterium as an experimental genetic system in our study can be summarized as follows:

As well-known, A. tumefaciens DNA consists of the indispensable genome DNA (bacterial chromosome, C58 (Wood et al., 2001); Henkel et al., 2014); and the dispensable plasmone DNA including a large circular tumor-inducing (Ti) (Van Larebeke et al., 1974; Currier \& Nester, 1976) plasmid responsible for virulence and tumor-induction in infected plants. The most but not all plasmid-genes are expressed in the bacterium living as vegetative in the rhizosphere. The vir genes, which are responsible for virulence, are inducible by chemicals (phenolic, - and sugar compounds) released from wounded plant tissues through the virA membrane histidine kinase receptor. VirA protein then phosphorylates the transcription activator vir $\mathrm{G}$, which binds to virbox sequences, located in the promoter regions of vir genes (Koncz, personal communication).

The genes encoding for enzymes synthetizing of tumor-specific compounds (including opines) are located in the transfer (T-DNA) region that is being inserted into the plant chromosomes, (Chilton et al., 1977) and have all signals necessary for expression in plants during crown-gall tumor formation (Koncz et al; 1983).

The T-DNA located opine-synthase genes are responsible for the synthesis of respective (nopaline, - octopine, or agropine -type) opines characteristic for a given Agrobacterium strain; while enzymes catabolizing (only the respective) opine are located outside of the T-DNA region. Agrobacterium strains are scored as nopaline (NOP), octopine (OCT) and agropine, as well as L, L,-succinamopine (AGR) opine-catabolizing ones (Montoya et al., 1977; Guyon et al., 1980).

\section{(For more details, see Supplementary material (Suppl. Text 1; Table S1).}


A given sensitivity/resistance $(\mathrm{S} / \mathrm{R})$ phenotype could be a consequence of more than one mechanism. Genes responsible for S/R phenotypes to EMA_PF2 may be located either on the chromosome; or on the Ti plasmid; or on the second large cryptic plasmid, (in the case of C58 strains, on pAtC58). If S/R phenotypes to EMA_PF2 were plasmid-related, genetic studies could be carried out by complementation analysis in Agrobacterium, (Hoekema, 1983). A toolkit for genetic analysis may also include comparisons of $\mathrm{S} / \mathrm{R}$ phenotypes of strains with different genetic background; such as of different opine type and of plasmid state. For the latter, wildtype, plasmid-cured and helper-plasmid harboring strains producing / catabolizing the same opine are worthwhile to compare. The mutant hunt and mutation analysis of candidate sequences is another way of genetic analysis and reproducible methodology has also been available in Agrobacterium (Koekman et al., 1979; Klapwijk \& Schilperoort, 1979; Ooms et al., 1980; Ooms et al., 1981; Ooms et al., 1982). There are three more unique attributes provided by the Agrobacterium genetic analytical system. First, that the Ti and RI plasmids of different origin are compatible and mutually exchangeable. Second, the "DNA-content" of the T-DNA region flanked by border sequences (Jen \& Chilton, 1986) could "freely" be replaced by other sequences. Third, the existence and special function of (prokaryotic) vir genes which can mobilize and activate T-DNA cassettes. These genes are coding for Vir proteins. The latter play a key role in Type 4 secretion (conjugation of the T-DNA) and processing the T-DNA borders trans by using the virD1/2 relaxation complex , allowing whose function is to mobilize the $\mathrm{T}$ DNA region, (whatever DNA sequences are inside), which cannot be imagine without severely influencing the cell membranes. The greatest advantage from our aspects is that they are capable of acting either from cis or in trans position (Csaba Koncz, personal communication).

Many Agrobacterium genomes and plasmids are fully sequenced. Furthermore, the researcher can also benefit from the unique option that partial heterozygotes could be constructed for plasmid segments from resistant and sensitive Agrobacterium strains; inserting either by a compatible plasmid from another strain; or selected sequences inserted into a binary vector; and applying complementation strategy called binary vector strategy, suggested by (Hoekema, 1983).

\section{MATERIAL AND METHODS}

\subsection{Bacterium Strains}

\subsubsection{Source of the strains and culture}

EMA and EMC Xenorhabdus strains originated from the Fodor Laboratory (Lengyel et al., 2005). Agrobacterium tumefaciens (HP1836 - HP1843) strains were from the frozen stock collection of F. Olasz. HP1836 - HP1840 had been deposited there by B. Dudás; HP1841 by D. Silhavy; HP1842 by V. Tisza, and HP1843 by G. B. Kiss. Agrobacterium tumefaciens SZL1, SZL2, SZL3, SZL4, and SZL5 were provided by László Szabados, (BRC, Hungarian Academy of Sciences, Szeged, Hungary. Agrobacterium and Xenorhabdus strains were grown and cultured according to the respective routine protocols of (Ausubel et al., 1999); Leclerc \& Boemare, 1991); Wise Liu and Binns 2006) All the in vitro bioassays were carried out in Luria Bertani broth and/or Luria Bertani Agar. 
Xenorhabdus budapestensis (EMA) isolated from Steinernema bicornutum was discovered and identified by us (Lengyel et al., 2005). Samples were deposited in DSMZ (DSMZ-Deutsche Sammlung von Mikroorganismen und Zellkulturen GmbH, Inhoffenstr. 7B, - 38124 Braunschweig - Germany; (http://www.dsmz.de ) as DSM16342 in 2004. It has also been deposited in Hungary (asAF13); and also in the Laboratory of Professor Heidi Goodrich-Blair (Department of Bacteriology, University of Wisconsin -Madison, Madison, WI, USA) as HGB033. A spontaneous rifampicin resistant mutant strain was isolated from HGB033 by András Fodor and also deposited there as HGB2238. (Some comparative tests also used the antibiotic-producing $X$. szentirmaii HGB036, as well as the spontaneous rifampicin resistant HGB2239 strain isolated from HGB036 by A. Fodor). All information concerning keeping, culturing, fermenting and bio-assaying EMA has previously been reported (Furgani et al., 2008; Böszörményi et al., 2009; Vozik et al., 2015).

\section{$\underline{2.1 .3 ~ T e s t ~ o r g a n i s m s ~}$}

\subsubsection{Test organisms used for evaluating the antimicrobial potentials of peptide-preparations}

As a Gram-negative test organism, the double resistant $\left(\mathrm{Km}^{\mathrm{R}} ; \mathrm{Cm}^{\mathrm{R}}\right) \mathrm{HGB} 2226$ E. coli strain was constructed in the Laboratory of Heidi Goodrich-Blair (in the Department of Bacteriology of the University of Wisconsin - Madison, Madison, WI, USA). The plasmid pPG1: Tn10 Km, a derivative of pLOFKm (vector: $A p \AA$, Tn10: Km) had provided by János Kiss, which had been constructed in the Arber Laboratory (Switzerland) by inserting a $\mathrm{Cm}$ cassette into the Amp region. pPG1 was introduced into S17 $\lambda$ pir to make strain HGB2226 by electroporation (by A. Fodor, Kristen Murfin, and Terra Maurer).

As negative (EMA_PF2 sensitive controls, other antibiotic multiresistant resistant $\boldsymbol{E}$. coli strains were used, including HGB 1333 /BW29427 (Dap-requiring, $\mathrm{Cm}^{\mathrm{R}}$ ) from H. GoodrichBlair); ABC 0801 (harboring plasmid with KK88 antigen; KmR, CmR, SmR, TcR); ABC 1609 (with plasmid TcA1; $\mathrm{Km}^{\mathrm{R}}, \mathrm{Ap}^{\mathrm{R}}$, / $\mathrm{Sm}^{\mathrm{S}}, \mathrm{Sp}^{\mathrm{S}}, \mathrm{Gm}^{\mathrm{S}}$ ); ABC 0156 (TG90nal ${ }^{\mathrm{R}}$; R55 with integrated $\mathrm{SG} 11$ genomic island; $\mathrm{Cm}^{\mathrm{R}}, \mathrm{Km}^{\mathrm{R}}, \mathrm{Sul}^{\mathrm{R}}, \mathrm{Sm}^{\mathrm{R}}, \mathrm{Ap}^{\mathrm{R}}$, $\mathrm{Rif}^{\mathrm{R}}, \mathrm{Ery}^{\mathrm{R}}$ ) from F. Olasz; ABC 0785 (hly+, sta, stb; plasmids: pTC, 18ac; Tc ${ }^{R}$, from B. Nagy); ABC 1611 (Serotype: K12; pR16A; Km $\mathrm{Ap}^{\mathrm{R}}, \mathrm{Sm}^{\mathrm{R}}, \mathrm{Sp}^{\mathrm{S}}, \mathrm{Gm}^{\mathrm{S}}$ ) from P. Dublet, (personal com); ABC 1499 (Human clinical isolate, $\mathrm{Km}^{\mathrm{R}}$, $\mathrm{Gm}^{\mathrm{R}}, \mathrm{Cm}^{\mathrm{R}}, \mathrm{Flo}^{\mathrm{R}}, \mathrm{Sm}^{\mathrm{R}}, \mathrm{Tc}^{\mathrm{R}}$ ) from F. De la Cruz (personal com.; ABC 0280 (Human clinical isolate A3 ${ }^{\mathrm{R}} ; \mathrm{Cm}^{\mathrm{R}}, \mathrm{Km}^{\mathrm{R}}, \mathrm{Sul}^{\mathrm{R}}, \mathrm{Sm}^{\mathrm{R}}, \mathrm{Ap}^{\mathrm{R}}$, Rif ${ }^{\mathrm{R}}$, Ery ${ }^{\mathrm{R}}$ ) A. Cloeackert, personal com. Also Salmonella strains: $S$. tiphymurium ABC 0159 (Natural isolate, SG11 genomic island, $\mathrm{Cm}^{\mathrm{R}}$, $\mathrm{Ap}^{\mathrm{R}} \mathrm{Tc}^{\mathrm{R}}, \mathrm{Sm}^{\mathrm{R}}, \mathrm{Rif}^{\mathrm{R}}$ ); S. tiphymurium ABC 0208, (Natural isolate, SG11 genomic island; $\mathrm{Cm}^{\mathrm{R}}$,

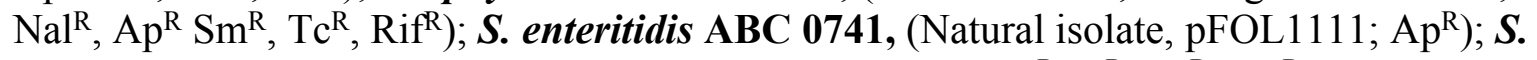
enteridis ABC 1844 (Serotype LT2; recA1; srl-202::Tn10 $\mathrm{Tc}^{\mathrm{R}}$ rif $^{\mathrm{R}}$; $\mathrm{Tc}^{\mathrm{R}}$, $\mathrm{Rif}^{\mathrm{R}}$ ) and $\boldsymbol{S}$. infantis ABC 1748 (Natural isolate Rif $^{\mathrm{R}}, \mathrm{Sp}^{\mathrm{R}} \mathrm{Ery}^{\mathrm{R}}, \mathrm{Su}^{\mathrm{R}}$ sulfamethoxazole / $\mathrm{Sm}^{\mathrm{R}}$ ) all from F. Olasz.

As a Gram-positive test organism, Staphylococcus aureus (SA) JE commercial strain (J.C. Ensign, unpublished) from Dr. J.C. Ensign's Lab was used.

269 As a fungal target, s the Gram-positive and Candida albicans (CA) JE strain (J.C.

270 Ensign, unpublished) was used as a fungal target for testing each preparation for antimicrobial activity in Agar Diffusion Bioassays, which were carried out as described (Vozik et al. 2015) 
with minor, actual modifications. This strain was used as an antibiotic double resistant $\left(\mathrm{Km}^{\mathrm{R}}\right.$; $\left.\mathrm{Cm}^{\mathrm{R}}\right)$ E. coli strain.

\subsubsection{Xenorhabdus strains as test organisms.}

HGB1795 is a transposon-induced insertion mutant of the XNC1_2022 gene (Gene ID: 9430524; Gene Page Link: NCBI UniProtKB; Locus Tag: XNC1_2022 see gene page for GenePage for the XNC1_2022 gene EcoGene-RefSeq) from Xenorhabdus nematophila (strain ATCC 19061 / DSM 3370 / LMG 1036 / NCIB 9965 / AN6), provided by Prof. Helge Bode, via Prof. Heidi Goodrich-Blair. The reason why we involved this mutant into this study on EMA_PF resistance studies is that previously Bicornutin A was believed as the active EMA antibiotic molecule, (Böszörményi et al., 2009 and XNC1_2022 gene of X. nematophila was believed to be a homologue of Xenorhabdus budapestensis NrpS (nrpS) gene, (GenBank: Accession Number is JX424818.1; gene synonym="bicA) which is responsible for the biosynthesis of Bicornutin A, (Fuchs et al., 2012). It turned out that it is not the case. However, some role in the scenario related to antibiotics activity and self-resistance cannot be ruled out, since the coexistence of Bicornutin A and fabclavine in our peptide-preparations.

Other Xenorhabdus strains were used as positive (resistant) controls, namely $X$. budapestensis HGB033 and HGB2238 (rif $\left.{ }^{\mathrm{R}}\right)$, X. szentirmaii HGB036, HGB2239 $\left(\right.$ rif $\left.^{\mathrm{R}}\right), X$. nematophila ATCC 19061 (from S. A. Forst), HGB081 (rif $\left.{ }^{\mathrm{R}}\right)$, and HGB1789 (rif $^{\mathrm{R}}$ ).

\subsubsection{Agrobacterium strains used in this study}

In order to reveal the sensitivity $(\mathrm{S})$ / resistance $(\mathrm{R})$ phenotypes to the antimicrobial peptide complex, we choose Agrobacterium strains of different genotype for in vitro liquid bio-assaying of EMA_PF2 on them. We worked on strains of different opine type and those on of different plasmid state within the opine groups.

We choose 4 agropine (L, L, - succinamopine, AGR) - catabolizing strains: $A 281$ (Guyon et al., 1980; Hood et al., 1986); AGL1 (Lazo, Stein and Ludwig, 1991); EHA105 (Hood et al., 1993); and $A 4 T$ (White and Nester, 1980; Petit et al., 1982; Jouanin et al, 1986; Slater et al, 2009). All of them are C58Rif ${ }^{\mathrm{R}}$ strains. All but A4T have a C58 ("S") chromosome - (the abbreviation indicates the geographic origin (Seattle) of strain A136 (C58 (Rif®), its chromosome also called "Seattle C58"); the sequence of which is slightly different from that of the previously discovered and sequenced "Gent/Leiden C58C" chromosome of nopaline catabolizing plasmid-cured strains (Dr. Paul J.J. Hooykaas, personal communication). A281 has a wild-type C58 (S) (Rif囚) chromosome from one of its ancestor, (the nopaline-catabolizing A136); and an intact, virulent agropine-catabolizing pBo542 [T-DNA] (+) plasmid (from its other ancestor, Bo542). A281 is a hyper, - (Hood et al, 1986; 1987); and also a super, - (Jin et al., 1987)) virulent strain. A known sequence of the pTiBo542 plasmid, outside the T-DNA box (Hood et al, 1986; (Komari, Halperin and Nester, 1986) is responsible for both hyper, - and super-virulence. The intact pTiBo542 plasmid has the T-DNA cassette, containing genes responsible for the synthesis of tumor-opines L, L-SAP, LOP, AGR. The disarmed-DNA deleted remainder sequence, called pEHA 101, contains genes coding for catabolizing enzymes of these opines. AGL1 is a disarmed derivative of A281 with a mutated C58 (S) (Rif® chromosome with a deletion in the in the RecA gene; its exact genotype is $\left(\mathrm{C} 58(\mathrm{~S}), \operatorname{RecA}:\right.$ bla; Rif ${ }^{\circledR}$ Carb ${ }^{\circledR}$, and is called AGL0; pEHA101. (The pEHA101= pTiBo542 DEL-T-DNA plasmid). The plasmid markers are NalR Mop (+) 
(Lazo, Stein and Ludwig, 1991); see also DNA Cloning Service, www.dna-

315 cloning.com). EHA105_is an indirect derivative of the intact plasmid from A281 (pTiBo542). It pEHA101 and by Gen ${ }^{\circledR}$ (Hood et al., 1993). (Previously pEHA101 had similarly been created from the wild-type (pTiBo542) when the T-DNA was replaced by KmR, (Hood et al., 1986). The genotype is C58(S) Rif® (pTiBo542DT-DNA = pEHA105 / / pBIN-19 - intronGus100$\left.\mathrm{Km}{ }^{\circledR}\right)$. (See also: (http://www.springerlink.com//content/t02h1486p1862715/). A4T is an agropine-catabolizing helper strain of "Gent/Leiden C58C" chromosome; and harbors a T-DNAdeleted (disarmed, helper [T-DNA] (-)] A4T plasmid originated from A. rhizogenes; and the binary vector pBIN19 intron (Gus Km®) (Bevan, 1984). For more details on $A$. rhizogenes helper plasmid harboring strains and their agro-biotechnological importance, see review (Taylor et al., 2006).

As for the NOP strains, we did not have a chance to the virulent wild-type ([T-DNS]) (+) strain. 5 of the 6 (HP1836 (C58C*-NOP1); HP1840 (C58C*-NOP2); HP1843 C58C*-NOP3; HP1841 (C58C1-NOP4); HP1842 (C58C1-NOP5) are plasmid-cured, (Uraji, Suzuki and Yoshida 2002); and only the SZL4 C58C1- pMP90 - NOP6 harbors the disarmed (helper, T-DNA deleted, pTiC58 [T-DNA [(-) called pMP90) plasmid, (Koncz and Shell, 1986). Each of them has C58 chromosome (Wood et al, 2001). The SZL4 (C58C1-pMP90-NOP6 strain has (the original "Gent/Leiden") C58C chromosome. (Koncz and Schell, 1986), The C58 chromosomes of the other 5 are other (Hungarian) isolate has not been sequenced yet. The genome-selective marker for HP1836 (C58C*-NOP1); HP1840 (C58C*-NOP2) and HP1843 (C58C*-NOP3) strains are naladixic acid resistance $\left(\mathrm{Nal}{ }^{\circledR}\right)$; while that for HP1841 (C58C1-NOP4); HP1842 C58C1NOP5; and C58C1-pMP90-NOP6 are of rifampicin resistance (Rif () .

As for the OCT strains, we did not have a chance to work either on the ancestor wild-type strain, harboring the virulent pTiAch5 [T-DNA] $(+)$ plasmid; nor on the first disarmed derivative of that plasmid is LBA4213 (Ooms et al., 1982); any plasmid-cured OCT strains. We worked on (HP1837 LBA4404/0-OCT1 and SZL2 LBA4404/pBIN-OCT2) strains. They both have the Ach5 chromosome [38], Henkel et al, 2014), and the chromosomal marker for them is Rif®. Each of the two strains, HP1837 (LBA4404/0-OCT1) and SZL2 (LBA4404/pBINOCT2), strains harbor the disarmed T-DNA deleted helper plasmid pAL 4404; (as known, encoding genes needed for both T-DNA transfer; and octopine degradation (Klapwijk, \& Schilperoort, 1979; Dessaux et al., 1988). The plasmid marker is Sm.

All these are summarized in Table 1 (see Tables).

\subsection{Preparation of Antimicrobial Peptide Complexes from EMA}

\section{(For more details: see Supplementary Material, Table S2)}

\subsubsection{Preparation of Sterile Cell-Free Culture Media (CFCM) and Antimicrobial Active} Peptide Factions from $X$. budapestensis (EMA) strains

\subsubsection{Isolation of Amberlite XAD 1148 ${ }^{\circledR}-$ bound Methanol-Eluted Peptide-rich Fraction (PF)}

The preparation of cell-free conditioned media (CFCM), and obtaining an antimicrobials active peptide-rich fraction (PF) from EMA by using amberlite adsorption followed by methanol (MeOH) elution, as published by ourselves earlier (Furgani et al., 2008; 
Böszörményi et al., 2009; Vozik et al., 2015). Samples of $10 \mathrm{mg} / \mathrm{ml}$ stock solution were kept frozen and then diluted freshly to $1 \mathrm{mg} / \mathrm{ml}$ working solutions just before each experiment. New preparations from HGB033 (deposited in UW Madison, Madison, WI, USA) and from the spontaneous Rif ${ }^{\circledR}$ mutant HGB2238 Rif ${ }^{\circ}$ from HGB033 were considered and handled as identical due to the HPLC profile and antimicrobial activity on the same targets.

\subsubsection{Ultrafiltration of Xenorhabdus PF Preparation}

$1 \mathrm{mg} / \mathrm{ml}$ water solutions of samples from EMA_PF preparation were administered to Amicon ${ }^{\circledR}$ Ultra15 to separate PF1 of $>10,000 \mathrm{Da}$ and $\mathrm{PF} \overline{2}<10,000 \mathrm{Da}$. In fact, EMA_PF2 was used as a model antimicrobial peptide complex in Agrobacterium experiments.

\subsubsection{Isolation of Antimicrobial Active Peptide Fraction (EMA $\left.A_{30}\right)$ by Reverse Phase Column Chromatography and AN/TF Elution}

The cell-free culture medium of the HGB2238 rifampicin resistant EMA strain was loaded onto a reverse phase column. The protocols described (Bowen \& Ensign, 1998; Bowen \& Ensign 2001), were used and modified, it was necessary, by using the Sigma protocol. All buffers and stock solutions for column chromatography were filtered through $0.2-\mu \mathrm{m}$-pore-size filters and autoclaved before use. The Sigma protocol was modified by Professor J. Ensign (unpublished) and we used his modified method. Briefly, the column was eluted with a mixture acetonitrile (AN), $\mathrm{CH} 3 \mathrm{CN}$ in $0.1 \%$ TFA (trifluoroacetic acid) at a flow rate of $0.4 \mathrm{ml} / \mathrm{min}$ at room temperature, that is $0,10,20,30,3540,50$ and $70 \mathrm{~V} / \mathrm{V} \%$ of AN containing $0.1 \%$ TFA. RPCC fractions were named by the number of the concentration of $\mathrm{AN}$, that eluted them from the column. The antimicrobial active peptides from EMA cell-free culture media was quantitatively eluted as one single faction by $30 \mathrm{~V} / \mathrm{V}$ AN (containing $0.1 \% \mathrm{TFA}$ ) and called $\mathrm{EMA}_{30}$. It exerted strong anti-Gram-positive, anti-fungal and anti-Gram/negative activity (data not shown) and was used for biochemical characterization.

\subsubsection{Antimicrobial active HPLC fractions}

Each HPLC sample was of given volume of a distilled water-dissolved and diluted freeze-dried antimicrobial peptide-complex solution, and, depending upon the column, the respective volumes were loaded, following the protocol. The HPLC protocols we used as described by Carr (2002). The eluent absorbance at 218 and $280 \mathrm{~nm}$ was routinely monitored. The peaks were detected at $168-215 \mathrm{~nm}$ and $168-280 \mathrm{~nm}$, respectively. Fractions were collected corresponding to the appearing peaks. Both EMAPF2 (the first HPLC sample was called af3; and the second run af6), and $\mathrm{EMA}_{30}$ (called AF103) were subjected to HPLC. As for af6, three HPLC peaks were detected, and 5 fractions from below the latest peak (called A2) exerted strong cytotoxic activities on both Gram-positive (SA) and Gram-negative (EC) targets; (see Results). Each experiment was repeated at least twice.

Three peaks from below the main peak of AF103 (called AF103-40; AF103-43 and AF103-44) exerted strong anti-Gram-negative, anti-Gram-positive and anti-Candida activity. These fractions were collected on $40^{\text {th }}, 43^{\text {rd }}$, and $44^{\text {th }}$ minutes of the 60 -min long HPLC run. None of the other fractions showed anti-Gram negative activity. These fractions were used in MALDI analysis. 


\subsection{Bioassays of Antimicrobial Peptide Complexes from EMA}

\section{2. 1 Methodology of Liquid Bioassay of EMA PF on Agrobacterium strains}

In vitro Liquid - Culture Bioassays of EMA PF on Agrobacterium strains were carried out in sterile 96-well tissue culture plates. Briefly, each culture had $200 \mu 1$ in the final volume; containing $100 \mu \mathrm{l}$ of $2 \mathrm{X}$ LB (supplemented with the respective selective antibiotics) and $95 \mu 1$ of a sterile water solution from the partially purified EMA PF, and inoculation of $5 \mu 1$ bacterial LB suspension from $100 \mu \mathrm{l}$; which contained 1 loop-size bacteria from single test bacterium colony grown on LBA plate in 24-h. For the three replicates, 3 independent clones were used. Purified, freeze-dried and re-dissolved preparations of EMA PF were used at 0, 30, 46, 60 and $75 \mu \mathrm{g} / \mathrm{ml}$ concentrations. We incubated the experimental plates for $24 \mathrm{~h}$ at $28{ }^{\circ} \mathrm{C}$, and then determined the OD values spectrophotometrically. The growth of bacteria was quantified on the basis of optical densities (OD values) of the cultures by screening the plates spectrophotometrically. The lower OD values indicated the stronger antibacterial activity of the EMA PF and higher sensitivity of the Agrobacterium strain tested. Other technical details of the experimental conditions of Liquid Bioassays had been published earlier, (Fodor et al., 2012; Vozik et al., 2015).

\subsubsection{Quantitative evaluations}

(If we had worked with a single antimicrobial active compound we should have an exact quantitative parameter if we determined the MIC values. We, however, have had a mixture of peptides of different antimicrobial activity, if we determine the quantitative amount of peptides which exerted a complete inhibitory effect on the tested bacterium strain, this "MIC" values cannot be considered as a quantitative data referring to one active component, but still provide an option for comparing the activity of our EMA_PF2 peptide complex in different strains. Therefore, we determined a value what we named the "gross MIC values" as if EMA_PF2 were a single antibiotic molecule, but we are aware of the fact that it is obviously not the case. The "gross MIC" value is suitable for comparisons of the activities of the EMA_PF2 on different targets, and this is the aim of this study).

Technically the "gross MIC values" of the EMA_PF2 were determined similarly as the MIC value of a single AMP, following the standard protocol, (see References: Wiegand, Hilpert \& Hancock, 2008; Clinical and Laboratory Standards Institute (CLSI, 2012). In fact, we determined the lowest growth-inhibiting dose of EMA_PF2 mixture (and separated fractions) on Agrobacterium and control (E. coli, Xenorhabdus, S. aureus) strains. We used LB broth for dilutions. Briefly, we worked in "SARSTEDT Multiple Well Plate 96-Well Round Bottom with Lid" culture plates, (Sarstedt, Inc., Newton, NC 28658, USA). Test bacteria were inoculated into a liquid growth medium containing different concentrations of EMA_PF2. Growth was determined on the base of the OD values of the liquid cultures, after incubation for $24 \mathrm{~h}$ (at $28{ }^{0} \mathrm{C}$, when the test targets were Agrobacterium and Xenorhabdus) and $12 \mathrm{~h}$ (at $37{ }^{\circ} \mathrm{C}$, when E. coli, S. aureus and Candida were the test organisms). When the OD value of a culture did not differ significantly from that of the freshly inoculated LB culture of the same composition, we cautiously considered the applied EMA PF concentration (given in $\mu \mathrm{g} / \mathrm{ml}$ ) as (gross) MIC90. In case of complete cytotoxicity, we kept the cultures for another two weeks on the bench top and 
442

443

444

445

446

447

448

449

450

451

452

453

454

455

456

457

458

459

460

461

462

463

464

465

466

467

468

469

470

471

472

473

474

475

476

477

478

479

480

481

482

considered as the final result if no growth was detected during this period of time. The "MIC"/in fact gross MIC - values added in the Tables and Figures are the means of three replicates. In Agar Diffusion Bioassays we -pipetted $100 \mu$ of samples into a hole in the center of a $1 / \mathrm{cm}$ thick LB agar plate. The respective plate was then overlaid by the suspension of the test organism, diluted with soft agar as published earlier (Vozik et al., 2015). The diameter of the inactivation zone was measured and the volume of agar media was calculated from that measurement. We considered these data as also informative but preliminary.

\subsection{Statistics}

The data analysis was performed using [SAS/STAT] software, Version [9.4] of the SAS System for [Windows X 64 Based Systems]; (Copyright (C) [2013 of copyright]; SAS Institute Inc. SAS, Cary, NC, USA. We used ANOVA and GLM Procedures alternatively following the requirements of the SAS 9.4 Software. The design of the experiment could be considered as a randomized complete block design with the number of the respective treatments, concentrations, and replicates. Data have been averaged as to allow the analysis of variance (ANOVA). The significance of differences of the means $(\alpha=0.05)$ was determined by using $t$ (Least Significant Difference, LSD) tests or Duncan's Multiple Range Tests, depending on the experiment. (For more details, see Supplementary Material, S_Text_2).

\section{RESULTS}

\subsection{Antimicrobial Activity Profile EMA_PF2 and EMA $A_{30}$}

Purification, description and of different AMP-preparations made during these experiments are listed in Appendix Supplementary Material Table S2. It can be seen that antimicrobial active fractions from EMA_CFCM could be separated either by amberlite adsorption or RFLP, and could be purified by HPLC. Off the preparations which proved antimicrobially active in each of the target organisms we have been dealing those presented in Table 2 except for EMA_PF1, which was found in very small quantity, and although it was very potent in each target organisms, we could know, whether it contained spontaneously polymerized active peptides, or large, originally inactive peptides which were "contaminated" with smaller antimicrobial active ones. The data of the antimicrobial activity of the different AMP-preparations on Gram-positive (S. aureus), Gram-negative (E. coli) targets, and on the X. nematophila mutant of HGB1795 and Candida (fungal) targets determined in Agar diffusion bioassays are presented in Table 2.

The data of the antimicrobial activity (measured in two different experiments) of the different concentrations of EMA_PF2 AMP-preparation on HGB1795 mutant and on its two parental $X$. nematophila clones (HGB081 and HGB1789) are presented in Fig 1A and Fig 1B, in comparison with different negative (Xenorhabdus) and positive (E. coli) control bacterium strains. The Statistical (ANOVA Procedure) Analysis of the data is present in Supplementary Material.

\subsection{HPLC and Maldi Profile of EMA_PF2 and EMA 30}


The EMA_PF2 preparation, which was used in the liquid bioassays on Agrobacterium strains,

484

485

486

487

488

489

490

491

492

493

494

495

496

497

498

499

500

501

502

503

504

505

506

507

508

509

510

511

512

513

515

516

517

518

514 One of them was the wild-type AGR strain, HP1838 (A281, of T-DNA (+) genotype). could be separated into three sharp peaks after repeated HPLC runs (Fig 2). Some but not all fractions collected from below the third (called A2) peak exerted both anti-Gram-positive and anti -Gram-negative activities when tested on S. aureus JE and E. coli (HGB2226) strains. AntiGram-Positive and Anti-Gram-Negative activities could not be separated such a way (Table 3).

The fraction collected from below the A2 derived from the HPLC purification of the EMA_PF2 peak exerted strong antimicrobial activity on each tested target strains. The MALDI profile of pooled fractions collected from below the A2 peak (Fig 3A) consisted of many peptides. At first sight, there are 5 dense spots within the region of $1300-1400 \mathrm{mZ}$. Many large peaks can be seen in the $1340-1366 \mathrm{~m} / \mathrm{Z}$ and $1373-1393 \mathrm{~m} / \mathrm{Z}$ regions, (Fig 3A).

The antimicrobially only active RFLP fraction purified from EMA CFCM was EMA 30 . It was extremely toxic for each of the target organisms. Further purification by HPLC showed that the antimicrobial activity was restricted to peptides collected from the $40-57$ min of the HPLC run, but only three fractions, collected in the $40^{\text {th }}, 43^{\text {rd }}$ and $44^{\text {th }}$ minutes exerted anti-Gram negative activity, on both E.coli HGB2226 and X. nematophila HGB1795, (Fig 4). The MALDI profile of pooled fractions collected from below AF103_43 (Fig 3B), (the most antimicrobial active HPLC fraction on each targets from $\mathrm{EMA}_{30}$ ), consisted of many peptides. On Fig 3B, similarly to Fig $3 \mathrm{~A}$, there are large peaks in the $1340-1366 \mathrm{~m} / \mathrm{Z}$ region, but, unlike to Fig 3A, there is no large peak in $1373-1393 \mathrm{~m} / \mathrm{Z}$ range (compare Fig 3B).

Thus, we figured that peptides between 1340 - $1366 \mathrm{~m} / \mathrm{Z}$ (believed to involve, $1346 \mathrm{~m} / \mathrm{Z}$, fabclavine) were responsible for the antimicrobial activity on four different EMA-sensitive targets.

The MALDI profiles of both the antimicrobial active (Fig 3 A, B) and inactive (not shown) HPLC fractions contained many peptide peaks in the range (about $946 \mathrm{~m} / \mathrm{Z}$ ), believed to be where Bicornutin A is located.

\subsection{Results of Liquid Culture Bioassays of EMA_PF2 on Agrobacterium strains of Different Genotype, Opine Type and Plasmid State}

The distribution of OD values as a function of EMA_PF concentrations are presented in Fig 5. (As for the respective statistics, see Supplementary material, Fig S1A - H; Tables S3 \& 4).

Of the 12 tested Agrobacterium strains, 8 were resistant to each applied doses (at somewhat different degrees), that is, that is, gross MIC values could not be determined.

4 strains were extreme sensitive, (represented by low OD $(<0.2)$ values even at each applied EMA_PF2), which corresponds to the detectable gross MIC values. The common feature of the 4 sensitive strains is that each harbors a T-DNA-deleted ( $\Delta$-TDNA) Ti plasmid. 3 of them were of AGR opine type, (A4T, HP1839, SZL3) and one (HP1837) was of OCT opine type (Fig 5). 
HP1838 was also resistant to unpurified EMA CFCM, while its $\Delta$-TDNA derivative, HP1839 was very sensitive (Fig 6A and B, respectively). When comparing the OD values of the four AGR strains, it the spectacular difference between the strain (HP1838) of T-DNA $(+)$ and of the three strains (HP1839, A4T and SZL3) of T-DNA (-) genotype. The latter three hardly differed from each other (Fig A, B, C and D). (As for the respective statistics related to the results of AGR strains, see Supplementary material, Table S5A, S5B).

As for the octopine strains, the picture is not so clear. SZL2 is resistant, HP1837 is sensitive, (Supplementary material Fig S3).

As for the studied NOP strains, each of them proved resistant to EMA_PF2 in in vitro liquid bioassay. Data on NOP strains are presented in Supplementary Material, FigS3; Suppl.

Text_6; Supplementary Material, S_Text_6; Table S7. The distribution patterns of the control and that of in the treated cultures are not the same, indicating a moderate and variable cytostatic (but no detectable cytotoxic) effects of EMA_PF2 on the examined strains.

\section{DISCUSSION}

We are interested in genetic analysis of natural resistance to natural AMP complexes, such as those produced by EPB nematode.symbibiotic bacteria. We believe that EMA_PF2 is a useful model, independently of its future perspectives as clinical, veterinary, or plant medicine. We did not purify individual peptides and did not determine their contribution to anti-microbial activity of the natural EMA_PF2 AMP complex, since we have been interested in the defense mechanisms against the natural antimicrobial peptide complex, EMA_F2, what we chose as a model. Our data indirectly confirm that the predominant component of the EMA_PF2 complex is the fabclavine (Fuchs et al., 2012, 2014), but are interested in the resistance mechanisms of $A$. tumefaciens toward the whole EMA complex of probably interacting antimicrobial peptides. This scenario may better represent the defense mechanisms developed by a soil-born Gram-negative bacterium (A. tumefaciens) to the natural antimicrobial peptide arsenal of entomopathogenic nematode bacterium complex.

We do not think that the toolkit of genetics should only be restricted to full-genom analysis, chemical and transposon mutagenesis and physical mapping. But, gene-interactions, such as epistasis, interallelic complementation etc., should be taken into consideration. Consequently, the effective system could provide options for using tools of classical Mendelian genetics. Our goal is to establish an experimental system for genetic analysis of resistance mechanisms against antimicrobial complexes. And, we believe that we found the system we have been looking for. We were not particularly interested in finding resistant mutant to a given AMP molecules, but to find the way to dissect the resistance mechanisms of a species which is resistant to the natural EMA_PF2 natural complex.

The known resistance mechanisms to antibiotics include enzymatic decomposition, efflux pumps (Nehme and Poole, 2005), permeability defects, and modifications of target sites (Fodor et al., 2017). We suppose that an evolutionarily-built resistance system against a group of interacting 
antimicrobial peptides may need another mechanism, the details of which have not yet been discovered. The structural differences of the membranes of cells in the different physiological states, such as presence or absence inducing factors prior to conjugation with the plant cell, may influence the permeability of peptide-like compounds similar to EMA_PF2.

We do not have any inforamtion concerning the membrane structure of cells harboring an intact or a disarmed Ti plasmid. Christie, (2004) published that the type IV secretion systems (T4SS) in bacteria are present in Agrobacterium, and used to deliver DNA as well as protein substrates from to plant cells. Considering that the T4SS is a complex built up from a several membrane proteins responding to environmental signals, (Christie, 2004), this might be a potential clue for understanding the differences between the responses to the studied AGR metabolizing strains.

Considering that the virulent wild-type A281 (HP1838) is resistant we concluded that $A$. tumefaciens is resistant to EMA_PF2. The question is whether this natural resistance has been based on the chromosome, on cross-resistance with other antibiotics, on the Ti-Plasmid, the opine-type, or something else.

Both C58 and Ach5 chromosomes were "represented" among the four sensitive strains as well as amongst the eight resistant strains. This seem to prove that the identity of the chromosome in the $\mathrm{S} / \mathrm{R}$ phenotype must be ruled out.

Considering that each of the three opine-types was "represented" amongst the 8 resistant strains, the role of the opine type may also be ruled out, although no NOP strain has been found as sensitive to EMA_PF2 in liquid test so far.

The common feature of the 4 sensitive Agrobacterium strains strain is that each harbors T-DNAdeleted ( $\Delta-$ TDNA) Ti plasmid. Three of them are agropine-catabolizing (AGR), and one of them (HP1837) was octopine-catabolizing (OCT). Two of the sensitive AGR strains (AGL1, EHA105) harbor $\Delta$-TDNA pTiA136Bo542, and the third $\Delta$-TDNA A4T (of A. rhizogenes origin). Two of them (EHA 105 and A4T) has been harboring a binary vector (pBIN-19-(IntronGus-Km $\left.{ }^{\circledR}\right)$, while AGL1 has not. Each of them was uniformly sensitive (Fig7B - 7D). They were also sensitive to EMA CFCM (Fig 6A).

At least for the AGR opine group it seems that $\Delta$-TDNA AGR Agrobacterium strains are sensitive, while that of intact pTiA136Bo542 plasmid is fully resistant. We do not have information about existence of plasmid-cured agropine strains, so we do not have a chance to determine their S/R phenotype, but our data support the hypothesis that, at least in this opine group is Ti plasmid dependent; more exactly T-DNA dependent.

If the plasmid-cured AGR strains had been viable and sensitive to EMA_PF2, (like the $\Delta-\mathrm{T}$ DNA ones), it would have been a proof of the existence of an R-gene, located in the T-DNA region of the pTiA136Bo542 plasmid. If the plasmid-cured AGR strains had been viable and resistant to EMA_PF2, (like the plasmid-cured NOP strains which had been previously reported as resistant to Agrocin 84 as well (Murphy \& Roberts, 1979); Ellis, Murphy and Kerr, et al., 1982; Ryder, Tate and Jones, et al., 1984; Farrand et al., 1985; Hayman and Farrand, 1988), it could be interpreted by more way than one. 
598

599

600

601

602

603

604

605

606

607

608

609

610

611

612

613

614

615

616

617

618

619

620

621

622

623

624

625

626

627

628

629

630

631

632

633

634

635

636

637

638

639

In the absence of plasmid-cured AGR strains we have only theoretical alternative explanations. Existence of an enzyme converting the non-toxic (or not permeable) EMA-peptide to a toxic (or permeable) molecule which is present (or active) in the sensitive strain but not present (or inactive) in the resistant strains would provide an explanation. The existence of a transmembrane protein transferring the toxic EMA-peptide into the cell which is present (or active) in the sensitive strain but not present (or inactive) in the resistant strains would provide another explanation. Considering that the strains harboring the Ti plasmid but missing the T-DNA cassette are sensitive, while strains missing the Ti plasmid, and consequently the T-DNA cassette are resistant, the only logical explanation is that the permeability (or AMP sensitivity) of the TDNA deleted Ti plasmid-harboring strains are different from that of both the wild-type and of the plasmid-cured strains. For experimentally testing this hypothesis we need to bioassay EMA_PF2 on T-DNA deleted, plasmid cured and wild type of (T-DNA) ${ }^{+}$genotype.

Some key experiments, what should be needed to answer some still open question could not be accomplished because of the unavailability of some strains. We did not find plasmid-cured AGR strain available in the literature. Neither we had a chance to bioassay of EMA_PF2 on wild-type ([T-DNA] (+) NOP and OCT strains of intact Ti plasmids. If they happened to be sensitive; like (the wild-type and plasmid-cured NOP strains to Agrocine 84), we have to take the Agrocin 84 model as a more general one. (The resistance/sensitivity of Agrobacterium strains to EMAproduced peptides is intriguing and may be based on fortuitous molecular structural similarities (as seemed to be the case for Agrocin 84), even we doubt these two bacterial groups (Xenorhabdus, Agrobacterium) would have ever encountered each other in nature). It is more critical that we did not use plasmid- selective antibiotics and cannot exclude the possibility that plasmids from SZL2 and SZL4 might be lost during propagation in liquid culture. Therefore, we should restrict our conclusions to the AGR group of Agrobacteria.

We did not have a chance to test wild-type NOP strains, only 5 plasmid-cured stains, each of them proved resistant both to the EMA CFCM (in agar diffusion test) and to the EMA PF_2 (in liquid bioassay); and 1 T-DNA deleted strain (SZL4), carrying a binary vector. Consequently we could not draw any conclusion related to his opine group, as such, even if each studied strain was resistant to EMA_PF2 in liquid bioassay. SZL4 was one of the most resistant to EMA PF_2 (in liquid bioassay, but sensitive to EMA CFCM (in agar diffusion test). There are three theoretical interpretation of this contradicting result. First, that SZL4 was sensitive in a compound present in CFCM but lost during the purification of EMA_PF2. Second: this strain may have lost its $\Delta$ TDNA plasmid during the incubation because we did not use plasmid-selective antibiotics, and therefore behaved, similarly to the resistant plasmid-cured NOP strains. We do not suppose, but could not rule out that presence of the binary vector in SZL4 might explain its resistance to EMA_PF2.

Although to search for $\mathrm{S} / \mathrm{R}$ phenotypes of $A$. rhizogenes strains was out of the scope of this work, we would like to expand our future research to the strains of this species, because expected similarities and differences between the two species may provide essential information for better understanding the mechanisms of natural resistance developed by these well-characterized 
640

641

642

643

644

645

646

647

648

649

650

651

652

653

654

655

656

657

658

659

660

661

662

663

664

665

666

667

668

669

670

671

672

673

674

675

676

677

678

species to multiple antimicrobial peptide complexes, and the joint point is A4T, a T-DNA delated agropine-catabolizing strain of sensitive (S) phenotype to the antimicrobial peptide/complex, EMA_PF2 .

\section{CONCUSIONS AND PERSPCTIVES}

If we had had only the results on the of L, L,-succinamopine utilizing Agrobacterium, strains, we should have been being able to draw unambiguous conclusions from the striking differences between the strong $\mathrm{R}$ phenotype of the intact ([T-DNA] (+) pTiBo542 plasmid harboring) A281 and unambiguously $S$ phenotype of all the examined disarmed ([T-DNA] (-) pTiBo542 plasmid harboring) strains, AGL1, EHA 105 and A4T. (Fig 5). These spectacular differences were also proven by the ANOVA-based statistical analyses (Suppl. material Table S3).

From the aspects of our goals the possible interpretation of the different $\mathrm{S} / \mathrm{R}$ phenotypes of different opines types are probably not of primary importance, but we may draw some conclusion

Our data suggest that the EMA_PF2 resistance must be Ti-plasmid related, more exactly TDNA-dependent.

One of the possible interpretations is that according to the logic of Mendelian basic genetics, the resistance (dominant) allele(s) should be located in the T-DNA-region of the agropinecatabolizing pTiBo542 plasmid. If it were the case, they must be expressed in our experimental conditions.

The general view is that T-DNA locates genes do not express in the bacterium only in the infected plants. Since the mains stream of the plant biotechnology-motivated research focused on T-DNA genes expressed in the infected plants, the earlier data (of Schroder et al., 1983, have almost been forgotten. They discovered (four) protein-coding T-DNA located genes which could be expressed in E. coli mini-cells, and their promoter activities were T-DNA located. Their functions have still been unknown, but supposed to mediating growth regulators.

The later discovered pTiBo542 was not subjected to this study, but since then it has been sequenced, and the identified genes from the left border to the right are identified, as follows: agrocinopine synthase; orf_Bo002; IS1312; orf_Bo003; orf_Bo004; orf_Bo005; indole-3acetamide hydrolase; tryptophan 2-monooxygenase; adenylate iso-pentenyl-transferase; hormone sensitivity modifying enzyme; protein $6 \mathrm{~b}$; succinamopine synthases; see https://www.ncbi.nlm.nih.gov/nuccore/DQ058764.1).

Of the predicted products of the unknown open reading frames (they should be: an $A$. rhizogenes rolB/C product-like; a DNA-binding helix; an integrase domain; an IS3-transposase; and an unknown protein, respectively) none of them one should be considered as "resistant gene" at the first sight. On the other hand, there are arguments supporting the hypothesis that (at least in the agropine group) the EMA_PF2 resistance is somehow T-DNA related. Each of A281, AGL1 and EHA105 strains have the same chromosome (C58 Rif®) and harboring L, L,succinamopine utilizing pBo542 strains of the same origin. There are two genetic differences 
between the A281 and AGL1 strains, but the question whether any of them could be an explanation of the differences in their S/R phenotype: (1) The presence of the TDNA region of the pTiBo542 in A281 (Van Larebeke et al., 1974), and its absence in AGL1; (2) The RecA chromosomal gene in A281 is the wild-type, while in AGL1 it has a deletion (Lazo et al. 1991). A281 is completely resistant; while the D-T-DNA AGL1 is fully sensitive to EMA_PF2.

Both AGL1 and EHA105 (Hood et al., 1993) harbors of D-T-DNA disarmed plasmid are fully sensitive to EMA_PF2. One of them (EHA105) is Rec A (+), and the other (AGL1) is Rec A (-). Consequently, the differences in the sensitivities of A281 and AGL1 to EMA_PF2 could not be a consequence of their differences in the Rec A locus; but rather of the presence / absences of the Bo542 [T-DNA] cassette. Another supporting argument is that agropine-catabolizing supersensitive AGR strain, A4T, (Petit et al., 1982, Jouanin et al., 1986) also harbors a disarmed, cryptic (RI) agropine-plasmid, not Bo542 but another one from another species, Agrobacterium rhizogenes, (Slater et al., 2009, see references: White and Nester,1980; Chilton et al., 1982; White et al., 1985; (Endoh et al.1990; Taylor et al., 2006; Mankin et al., 2007). The only common feature between A4, AGL1, and EHA105 is the absence of the T-DNA cassette from the respective AGR Ti plasmid.

Agrobacterium strains harbouring del-T-DNA plasmids and complementing DNA sequences (either in another plasmid or in binary vectors) within the cells may provide a suitable system for genetic analysis of resistance to antimicrobial peptides other than EMA_PF2.

Such an experimental system can be based on the existence of super-sensitive del-T-DNA pTiBo542 harboring L, L,-succinilopine-catabolising Agrobacterium strains and the beneficial situation that Ti plasmids fully compatible with each other and partial heterozygotes could be produced. The binary vector strategy of Hoekema (1983) could be adopted in such a way.

Despite of our primary interest to study the resistance mechanisms of Agrobacteria to complex interacting anti-microbial peptides, such as those comprise our model, EMA_PF2, it would be especially interesting to screen the previously identified individual antimicrobial peptides of Xenorhabdus and Photorhabdus origin, (see Parke et al., 2009; Gualtieri et al., 2009; Fuchs et al., 2012; Nollman, 2012; Fuchs et al., 2013; Li, Plésiat and Nikaido 2015; Xi et al., 2012); and especially the kolossin A, (Bode et al, 2016) in this Agrobacterium system.

\section{ACKNOWLEDGMENTS}

We express our appreciation and the sincerest thanks for the professional guidance of Professor Heidi Goodrich-Blair in the field of bacteriology. She was who kindly provided the strain HGB1975 and the needed direct and related sequence information, as well as many other E. coli and Xenorhabdus strains and equipment, lab infrastructure and consumables we needed.

Professor Jerald C. Ensign guided all work related to separation biotechnology, HPLC, RFLP and MALDI. We also thank people from their laboratories, especially Dr. Angel CasanovaTorres, Terra Maurer, Dr. Kristen Murfin; Mengy Cao, Neta Millet, Kai Hillman, and Daren Ginete for technical help. For his abundant intellectual help in connection with the Agrobacterium part at finalizing the MS we had to express our thanks to Dr. Csaba Koncz (Dr. Acad. Sci., PhD, Max Planck Institute for Plant Breeding Research, Cologne, Germany). 
The experiments in the University of Pannonia, Keszthely, Hungary) were kindly supported by Dr. András Takács, Head of the Institute of Plant Protection. We feel obliged to express our thanks to fellow scientist Sándor Józsa (University of Pannonia, Keszthely, Hungary) for his help with statistics, and to Mrs. Andrea Máthé-Fodor her support in completeing the Manuscript. We would like to express thanks and appreciations the professional technical help to the lab technicians in the Vet School for their invaluable technical help, especially Miss Éva Kolozsvári and Miss Teréz Halasi.

We are thankful for the generous intellecual and technical help of the Head of the OARDC/OSU Library, Mrs. Gwen Short, and her associate Mrs. Laura Appelgate who introduce us using ZOTERO. made it possible to complete the Manuscript.

\section{ADDITIONAL INFORMATIONS AND DECLARATIONS}

\section{Funding}

This project was supported by a Fulbright Grant Biological Science Grant (1214102) awarded to András Fodor to conduct research in the Laboratory of Heidi Goodrich-Blair at the Department of Bacteriology at University of Wisconsin-Madison, USA. Valent BioSciences also contributed to the Bench Costs with a Special Grant, (provided by R\&D Director, Dr. József Racskó).

\section{Competing interests}

Authors have declared that no competing interests exist.

\section{Authors' Contributions}

András Fodor, Ferenc Olasz and János Kiss designed the study. The experiments were $80 \%$ carried out about at Department of Bacteriology, of the University of Wisconsin-Madison, in Madison, WI, USA by Fulbright Research Grantee A. Fodor; by doing the bacterial studies in the Laboratory of Heidi Goodrich-Blair; Fermentation, HPLC, MALDI analysis and some of the bioassays in the Laboratory Jerald C. Ensign. Experiments (prior to Madison) were conducted in A. Fodor's laboratory at the University of Pannonia, Keszthely, Hungary, where EMA_PF were routinely produced by Dávid Vozik (tutor: Katalin Bélafi-Bakó); some bioassays on Agrobacterium strains were carried out by Ahmed Nour El-Deen and others by Erzsébet Böszörményi. Other experiments (just before and right after Madison) were carried out at the University of Veterinary Medicine, Budapest, Hungary by A. Fodor, László Makrai and László Fodor. Ferenc Olasz, János Kiss and László Szabados and provided Agrobacterium strains with the proper guidance, while Steven A. Forst provided the X. nematophila strain var-2. The statistical analysis was carried out by A. Fodor with the guidance of Muhammad Akbar Bin Abdul Ghaffar at the Ohio State University in Wooster, OH. J. Kiss, F. Olasz A. Fodor with the professional proofreading of Michael G. Klein made the manuscript completed. The final shaping of the figures was performed by $\mathbf{J}$. Kiss. 
756 Data availability

757 The following information was supplied regarding to data availability:

758 Experimental Data Analyzed by ANOVA Procedure: provided in the Supplemental Files

759 
792

793

794

\section{REFERENCES}

Aćimović SG, Zeng Q, McGhee GC, Sundin GW, Wise JC. 2015. Control of fire blight (Erwinia amylovora) on apple trees with trunk-injected plant resistance inducers and antibiotics, and assessment of induction of pathogenesis-related protein genes. Frontiers of Plant Science 6:16. doi: 10.3389/fpls.2015.00016. eCollection 2015

Akhurst RJ. 1982. Antibiotic activity of Xenorhabdus spp., bacteria symbiotically associated with insect pathogenic nematodes of the families Heterorhabditidae and Steinernematidae. $J$ Gen Microbiol.128:3061-3065. DOI: 10.1099/00221287-128-12-3061/ PMID: 7183749.

Antunes, L.C.S., Visca, P., Towner, K.J., 2014. Acinetobacter baumannii: evolution of a global pathogen. Pathogens and Diseases 71:292-301. https://doi.org/10.1111/2049-632X.12125

Ausubel FM, Brent R, Kingston RE, Moor DD, Seidman JG, Smith JA, Struhl K. (Eds.) 1999. Short Protocols in Molecular Biology: A Compendium of Methods from Current Protocols in Molecular Biology. pp. 1-1 - 1-6; 5-1 - 6-30. John Wiley \& Sons, New York

Balli EP, Venetis CA, Miyakis S. 2014. Systematic review and meta-analysis of linezolid versus daptomycin for treatment of vancomycin-resistant enterococcal bacteremia. Antimicrobial Agents and Chemotherapy. 58:734-739. doi: 10.1128/AAC.01289-13. Epub 2013 Nov 18. Review. PMID: 24247127 Free PMC

Bevan M, 1984. Binary Agrobacterium vectors for plant transformation. Nucleic Acid Research 12:8711-8721.

Bode HB. 2009. Entomopathogenic bacteria as a source of secondary metabolites. Current Opinions in Chemistry \& Biology 13:224-230. doi.org/10.1016/j.cbpa.2009.02.037

Bode E, Brachmann AO, Kegler C, Simsek R, Dauth C, Zhou Q, Kaiser M, Klemmt P, Bode HB. 2015a. Simple "on-demand" production of bioactive natural products. ChemBioChem 16:1115-1119. Doi: 1002/cbic.201500094

Bode HB, Brachmann AO, Jadhav KB, Seyfarth L, Dauth C, Fuchs SW, Kaiser M, Waterfield NR, Sack H, Heinemann SH, Arndt H-D. 2015b. Structure elucidation and activity of Kolossin A, the D-/L-pentadecapeptide product of a giant nonribosomal peptide synthetase. Angewandte Chemie International Edition 54:10352-10355. doi:10.1002/anie.201502835.

\section{Böszörményi E, Érsek T, Fodor A, Fodor AM, Földes LS, Hevesi M, Hogan JS, Katona Z,} Klein MG, Kormány A, Pekár S, Szentirmai A, Sztaricskai F, Taylor RA. 2009. Isolation and activity of Xenorhabdus antimicrobial compounds against the plant pathogens Erwinia amylovora and Phytophthora nicotianae. Journal of Applied Microbiology 107:746-759. DOI: 10.1111/j.1365-2672.2009.04249.x. Epub 2009 Mar 23 
Bowen DJ, Ensign JC. 1998. Purification and characterization of a high-molecular-weight insecticidal protein complex produced by the entomopathogenic bacterium Photorhabdus luminescens. Applied Environmental Microbiology 64:3029-3035. PMID: 9687469

Bowen DJ, Ensign JC. 2001. Isolation and characterization of intracellular protein inclusions produced by the entomopathogenic bacterium Photorhabdus luminescens. Applied Environmental Microbiology 67:4834-4841.

Cantas L, Shah, S. Q. A. L., Cavaco, M, Manaia, C.M, Walsh, F., Popowska, M, Garelick, H., Bürgmann, H. H., Sørum, H. 2013. A brief multi-disciplinary review on antimicrobial resistance in medicine and its linkage to the global environmental microbiota. Frontiers in Microbiology. 4: 96. DOI: 10.3389/fmicb.2013.00096 PMCID: PMC3653125.

Carr D 2002. The Handbook of Analysis and. Purification of Peptides and. Proteins by ReversedPhase HPLC. Presented by Vydac (The Separations Group). 17434 Mojave Street. Hesperia CA 92345 USA.

Chilton M-D, Drummond M, Merlo D, Sciaky D, Montoya A, Gordon M, Nester E. 1977. Stable incorporation of plasmid DNA into higher plant cells: the molecular basis of crown gall tumorigenesis. Cell 11:263-271.

Chilton M-D, Tepfer DA, Petit A, David C, Casse-Delbart F, Tempé J. 1982. Agrobacterium rhizogenes inserts T-DNA into the genomes of the host plant root cells. Nature 295:432-434.

Christie PJ. 2004. Type IV secretion: the Agrobacterium VirB/D4 and related conjugation systems. Biochimica et Biophysica Acta 1694:219-234. DOI:10.1016/j.bbamcr.2004.02.013

\section{CLSI: Performance Standards for Antimicrobial Disk Susceptibility Tests; Approved} Standard Eleventh Edition. CLSI document M02-A11. Wayne, PA: Clinical and Laboratory Standards Institute, 2012.

Cowles KN, Cowles CE, Richards GR, Martens EC, Goodrich-Blair H. 2007. The global regulator $L r p$ contributes to mutualism, pathogenesis and phenotypic variation in the bacterium Xenorhabdus nematophila. Cellular Microbiology 9:1311-1323. Epub 2007 Jan 11.

Currier TC, Nester EW. 1976. Evidence for diverse types of large plasmids in tumor- inducing strains of Agrobacterium. Journal of Bacteriology 126:157-165.

Davis MF, Peterson AE, Julian KG, Greene WH, Price LB, Nelson K, Whitener CJ, Silbergeld EK. 2013, Household risk factors for colonization with multidrug-resistant Staphylococcus aureus isolates. PLoS One 8, e54733. DOI: 10.1371/journal.pone.0054733. Epub 2013 Jan 24 PMCID: PMC3554652.

Dessaux Y, Guyon P, Petit A, Tempe J, Demarez M, Legrain C, Tate ME, Farrand SK. 1988. Opine utilization by Agrobacterium spp.: Octopine-type Ti plasmids encode two pathways for mannopinic acid degradation. Journal of Bacteriology 170:2939-2946. 
Dötsch A, Becker T, Pommerenke C, Magnowska Z, Jansch L, Haussler S. 2009. Genome wide identification of genetic determinants of antimicrobial drug resistance in Pseudomonas aeruginosa. Antimicrobial Agents and Chemotherapy 53:2522-2531. DOI: 10.1128/AAC.00035-09. Epub 2009 Mar 30.

Elis JG, Murphy PJ. 1981. Four new opines from crown gall tumors-their detection and properties. Molecular and General Genetics 181:36-43.

Ellis JG, Kerr A, Van Montagu M, Schell J. 1979. Agrobacterium genetic studies on agrocin 84 production and the biological control of crown gall. Physiological Plant Pathology 15:311-319.

Ellis JG, Murphy PJ, Kerr A. 1982. Isolation and properties of transfer regulatory mutants of the nopaline Ti plasmid pTiC58. Molecular and General Genetics 186:275-281.

Ellington MJ, Ganner M, Warner M, Cookson BD, Kearns AM. 2010. Polyclonal multiply antibiotic-resistant methicillin-resistant Staphylococcus aureus with Panton-Valentine leucocidin in England. Journal of Antimicrobial Chemotherapy 65:46-50. doi: 10.1093/jac/dkp386.

Endimiani A1, Hujer KM, Hujer AM, Bertschy I, Rossano A, Koch C, Gerber V, Francey T, Bonomo RA, Perreten V.. 2011. Acinetobacter baumannii isolates from pets and horses in Switzerland: molecular characterization and clinical data 2011. Journal of Antimicrobial Chemotherapy. 66: 2248-2254. DOI: 10.1093/jac/dkr289 PMC3172040.

Exner, M., Bhattacharya, S., Christiansen, B., Gebel, J., Groncy-Bermes, P., Hartemann, P., Peter Heeg, P., Ilschner, C., Kramer, A., Larson, E., Merkens, W., Mielke, M., Oltmanns, P., Ross, B., Rotter, M., Schmithausen, R. M., Sonntag, H.-G., Matthias Trautmann, M. 2017. Antibiotic resistance: What is so special about multidrug-resistant Gram-negative bacteria? GMS Hygiene and Infection Control 2017; 12, Doc05; Published online 2017 Apr 10. DOI: 10.3205/dgkh000290 PMCID: PMC5388835

Farrand SK, Slota J, Shim S, Kerr A. 1985. TnS insertions in the agrocin 84 plasmid: the conjugal nature of pAgK84 and the locations of determinants for transfer and agrocin 84 production. Plasmid 1:106-117.

Fodor A, Fodor AM, Forst S, Hogan J, Hevesi M, Klein MG, Stackebrandt E, Szentirmai A, Sztaricskai F. 2007. New aspects of Xenorhabdus research. In: Abstracts of the $11^{\text {th }}$ European Meeting of IOBC.WPRS Working Group "Insect Pathogens and Insect Parasitic Nematodes" in association with COST 862 Bacterial toxins for insect control” Ales (Gard) France, June 03-07 2007.

Fodor A, Fodor AM, Forst S, Hogan JS, Klein MG, Lehoczky É. 2010. Comparative analysis of antibacterial activities of Xenorhabdus species on related and non-related bacteria in vivo. Journal of Microbiology and Antimicrobials 2:30-35.

Fodor A, Varga I, Hevesi M, Máthé-Fodor A, Racsko J, Hogan JA. 2012. Novel anti-microbial peptides of Xenorhabdus origin against multidrug resistant plant pathogens, In: Bobbarala, V. (Ed.): Biochemistry, Genetics and Molecular Biology - A Search for Antibacterial Agents, 9:147-196. 
Fodor, A., Deák, P., Fodor, L., Makrai, L., Abate B.A., Muvevi, J., Klein, M.G. 2017. Multi Antibiotic Resistance in Bacteria: Selected Genetic and Evolutionary Aspects: a Review. Current Trends in Microbiology, Vol. 11, 2017. RT MB 127, in press (maybe delayed).

Forst S, Nealson K. 1996. Molecular biology of the symbiotic-pathogenic bacteria Xenorhabdus spp. and Photorhabdus spp. Microbial Review 60:21-43. Review.

Förster H, McGhee GC, Sundin GW, Adaskaveg JE. 2015. Characterization of streptomycin resistance in isolates of Erwinia amylovora in California. Phytopathology 105:1302-1310. DOI: 10.1094/PHYTO-03-15-0078-R. Epub 2015 Sep 28.

Fuchs SW, Christian C, Sachs CC, Kegler C, Nollmann FI, Karas M, Bode HB.2012. Neutral loss fragmentation pattern based screening for arginine-rich natural products in Xenorhabdus and Photorhabdus. Analytical Chemistry 84:6948-6955.

Fuchs SW, Grundmann F, Kurz M, Kaiser M, Bode HB. 2014. Fabclavines: Bioactive peptidepolyketide-polyamino hybrids from Xenorhabdus. ChemBioChem 15:512-516. DOI: 10.1002/cbic.201300802us

Furgani G, Böszörményi E, Fodor A, Máthé-Fodor A, Forst S, Hogan JS, Katona Z, Klein MG, Stackebrandt E, Szentirmai A, Sztaricskai F, Wolf SL. 2008. Xenorhabdus antibiotics: a comparative analysis and potential utility for controlling mastitis caused by bacteria. Journal of Applied Microbiology 104:745-758. http://dx.doi.org/10.1111/j.1365-2672.2007.0 3613.x.

Gebreyes, W. A. and Thakur, S. 2005. Multidrug-Resistant Salmonella enterica Serovar Muenchen from pigs and humans and potential interserovar transfer of antimicrobial resistance. Antimicrobial Agents and Chemotherapy. 49: 503-511. DOI: 10.1128/AAC.49.2.503-511.2005; PMCID: PMC547275.

Gilmore MS1, Lebreton F, van Schaik W. 2013. Genomic transition of enterococci from gut commensals to leading causes of multidrug-resistant hospital infection in the antibiotic era. Current Opinion in Microbiology 16: 10-16.

Gonçalves-de-Albuquerque, C.F., Silva, A.R., Burth, P., Rocco, P.R., Castro-Faria, M.V., Castro-Faria-Neto, H.C. 2016. Possible mechanisms of Pseudomonas aeruginosa-associated lung disease. Int J Med Microbiol. 306:20. doi: 10.1016/j.ijmm.2015.11.001. Epub 2015 Nov 22

Gualtieri M, Aumelas A, Thaler JO. 2009. Identification of a new antimicrobial lysine-rich cyclolipopeptide family from Xenorhabdus nematophila. Journal of Antibiotics 62:295-302.

Gualtieri M, Ogier J-C, Pagès S, Givaudan A, Gaudriault S. 2014. Draft genome sequence and annotation of the entomopathogenic $\backslash$ bacterium Xenorhabdus szentirmaii Strain DSM16338. Genome Announcements 2(2): e00190-14 genomea.asm.org 1).

Gupta N, Limbago BM, Patel JB, Kallen AJ.2011. Carbapenem-resistant Enterobacteriaceae: epidemiology and prevention. Clinical Infectious Diseases, 53: 60-67.

Gusberti M, Klemm U, Meier MS, Maurhofer M, Hunger-Glaser I. 2015. Fire blight control: The struggle goes on. A comparison of different fire blight control methods in Switzerland with 
respect to biosafety, efficacy and durability. International Journal of Environmental Research and Public Health 12:11422-11447. doi: 10.3390/ijerph120911422

Guyon P, Chilton M-D, Petit A, Tempo J. 1980. Agropine in "null-type" crown gall tumors: Evidence for generality of the opine concept. Proceedings of the National Academy of Science USA 77:2693-2697.

Hayman GT, Farrand SK. 1988. Characterization and mapping of the agrocinopine- agrocin 84 locus on the nopaline Ti plasmid pTiC58. Journal of Bacteriology 170:1759-1767.

Henkel CV, Dulk-Ras A, Zhang X, Hooykaas PJJ. 2014. Genome sequence of the octopine-type Agrobacterium tumefaciens Strain Ach5. Genome Announcements 2: e00225-14

Hirakata Y, Srikumar R, Poole K, Gotoh N, Suematsu T, Kohno S, Kamihira S, Hancock RE, Speert DP. 2002. Multidrug efflux systems play an important role in the invasiveness of Pseudomonas aeruginosa. Journal of Experimental Medicine 196:109-118. doi: 10.1084/jem.20020005

Hoekema A, Hirsch PR, Hooykaas PJJ, Schilperoort RA. 1983. A binary plant vector strategy based on separation of vir- and T-region of the Agrobacterium tumefaciens Ti-plasmid. Nature 303:179-180.

Hood EE, Helmer GL, Fraley RT, Chilton M.-D. 1986. The hypervirulence of Agrobacterium tumefaciens A281 is encoded in a region of pTiBo542 outside of T-DNA. Journal of Bacteriology 168:1291-1301.

Hood EE, Helmer GL, Fraley RT, Chilton MD. 1987. Virulence of Agrobacterium tumefaciens strain A281 on legumes. Plant Physiology 83:529-534.

Hood EE, Gelvin SB, Melchers LS, Hoekema A. 1993. New Agrobacterium helper plasmids for gene transfer to plants. Transgenic Research 2:208-218.

Houard J, Aumelas A, Noël T, Sylvie Pages S, Givaudan A, Fitton-Ouhab V, Villain-Guillot P, Gualtieri M. 2013. Cabanillasin, a new antifungal metabolite, produced by entomopathogenic Xenorhabdus cabanillasii JM26. Journal of Antibiotics 66:617-620. DOI:10.1038/ja.2013.58;

Jen GC, Chilton M-D. 1986. Activity of T-DNA borders in plant cell transformation by mini-T Plasmids. Journal of Bacteriology 166:491-499.

Jenssen H, Hamill P, Hancock RE. 2006. Peptide antimicrobial agents. Clinical Microbiology Review 19:491-511. DOI: 10.1128/CMR.00056-05

Jeukens J, Kukavica-Ibrulj I, Emond-Rheault JG, Freschi L, Levesque RC. 2017. Comparative genomics of a drug-resistant Pseudomonas aeruginosa panel and the challenges of antimicrobial resistance prediction from genomes. FEMS Microbiology Letters 364, (18), 2 October 2017), doi: 10.1093/femsle/fnx161. PMID: 28922838 
Jin S, Komari T, Milton P, Gordon MP, Nester EW. 1987. Genes Responsible for the supervirulence Phenotype of Agrobacterium tumefaciens A281. Journal of Bacteriology 169:4417-4425.

Jouanin L, Tourneur J, Tourneur C, Casse-Delbart F. 1986. Restriction maps and homologies of the three plasmids of Agrobacterium rhizogenes Strain A4. Plasmid 16:124-134.

Kádár B, Kocsis B, Nagy, K, Szabó, D. 2013. The renaissance of polymyxins. Current Medicinal Chemistry Journal 20: 3759-3773. PMID: 23895690

Klapwijk PM, Schilperoort RA 1979. Negative control of octopine degradation and transfer genes of octopin Ti plasmids in Agrobacterium tumefaciens. Journal of Bacteriology 132:424-431.

Koekman BP, Ooms G, Klapwijk PM, Schilperoort RA. 1979. Genetic map of an octopine Tiplasmid. Plasmid 2:346-357.

Komari T, Halperin W, Nester EW. 1986. Physical and functional map of supervirulent Agrobacterium tumefaciens tumor-inducing plasmid pTiBoS42. Journal of Bacteriology 166:8894.

Koncz C, Schell J. 1986. The promoter of TL-DNA gene 5 controls the tissue-specific expression of chimaeric genes carried by a novel type of Agrobacterium binary vector. Molecular and General Genetics 204:383-396.

Koncz Cs, DeGreve H, Andre D, Deboeck F, Van Montagu M, Schell J. 1983. The opine synthase genes carried by Ti plasmids contain all signals necessary for expression in plants. EMBO Journal 2:1597-1603.

Kosikowska P, Lesner A.2016. Antimicrobial peptides (AMPs) as drug candidates: a patent review (2003-2015) Expert Opinion on Therapeutic Patents, 26:689-702. doi: 10.1080/13543776.2016.1176149. Epub 2016 Apr 22

Lazo GR, Stein PA, Ludwig RA. 1991. A DNA transformation-competent Arabidopsis genomic library in Agrobacterium. Biotechnology (N Y) 9: 963-967.

Leclerc MC, Boemare NE. 1991. Plasmids and phase variation in Xenorhabdus spp. Applied Environmental Microbiology 57:2597-3601.

Lee CR, Lee JH, Park M, Park KS, Bae IK, Kim YB, Cha CJ, Jeong BC, Lee SH. 2017. Biology of Acinetobacter baumannii: Pathogenesis, Antibiotic Resistance Mechanisms, and Prospective Treatment Options. Frontiers in Cellular and Infection Microbiology, 7:55. doi: 10.3389/fcimb.2017.00055. eCollection 2017

Lengyel K, Lang E, Fodor A, Szállás E, Schumann P, Stackebrandt E. 2005. Description of four novel species of Xenorhabdus, family Enterobacteriaceae: Xenorhabdus budapestensis sp. nov., Xenorhabdus ehlersii sp. nov., Xenorhabdus innexi sp. nov., and Xenorhabdus szentirmaii sp. nov. Systematics of Applied Microbiology 28:115-122. Erratum in: Systematics of Applied Microbiology 30:83; also in March/April 2014 Volume 2 Issue 2 e00190-14 Genome 
Announcements genomea.asm.org. Xenorhabdus budapestensis sp. Nov., Xenorhabdus ehlersii sp. Nov., Xenorhabdus innexi sp. Nov., and Xenorhabdus szentirmaii sp. Nov. Systematics of Applied Microbiology 28:115-122. http://dx.doi.org/10.1 016/j.syapm.2004.10.004.

Li, X.-Z., Plésiat, P., Hiroshi Nikaido, H. 2015. The Challenge of Efflux-Mediated Antibiotic Resistance in Gram-Negative Bacteria. Clinical Microbiology Reviews 28: 337-418. DOI: 10.1128/CMR.00117-14 PMCID: PMC4402952.

Lin L, Nonejuie P, Munguia J, Hollands A, Olson J, Dam Q, Kumaraswamy M, Rivera H Jr, Corriden RF, Rohde M, Hensler ME, Burkart MD, Pogliano J, Sakoulas G, Nizet V. 2013. Azithromycin synergizes with cationic antimicrobial peptides to exert bactericidal and therapeutic activity against highly multidrug-resistant gram-negative bacterial pathogens. EBioMedicine 2:690-698.

McManus PS, Stockwell VO, Sundin GW, Jones AL. 2002. Antibiotic use in plant agriculture. Annual Review of Phytopathology 40:443-465. DOI: 10.1146/annurev.phyto.40.120301.093927

McManus, BA., Coleman, DC., Deasy, EC., Brennan, GI., O’ Connell, B., Monecke, S., Ehricht, R., Leggett, Leonard, NB., Anna C. Shore, AC. 2015. Comparative Genotypes, Staphylococcal Cassette Chromosome mec (SCCmec) Genes and Antimicrobial Resistance amongst Staphylococcus epidermidis and Staphylococcus haemolyticus isolates from infections in humans and companion animals. PLoS One 10: e0138079. DOI: 10.1371/journal.pone.0138079. eCollection 2015 PMCID: PMC4574763.

Marques, C., Gama, L. T., Belas, A., Bergström, K., Beurlet, S., Briend-Marchal, A., Broens, E.M., Costa, M., Criel, D., Damborg, P., van Dijk, M. A. M., van Dongen, A. M., Dorsch, R., Espada, C.M., Gerber, B., Kritsepi-Konstantinou, M., Loncaric, I., Mion, D., Misic, D., Movilla, R., Overesch, G., Perreten,V., Roura, X., Steenbergen, J., Timofte, D., Wolf, G., Zanoni, R. G. Schmitt, S., Guardabassi, L., Pomba, C. 2016. European multicenter study on antimicrobial resistance in bacteria isolated from companion animal urinary tract infections. BMC Veterinary Research 2016; 12:213.DOI: 10.1186/s12917-016-0840-3 PMCID: PMC5034465.

Miller, W. R., Munita, J. M. and Arias, C. A. 2014. Mechanisms of antibiotic resistance in enterococci Expert Review of Anti-infective Therapy 2014 Oct; 12:1221-1236. DOI: 10.1586/14787210.2014.956092. Review. PMID: 25199988 Free PMC Article.

Mojsoska B1, Jenssen H2.2015. Peptides and Peptidomimetics for Antimicrobial Drug Design. Pharmaceuticals (Basel). 2015 Jul 13; 8:366-415. doi: 10.3390/ph8030366. Review. PMID: 26184232 Free PMC Article

Montoya AI, Chilton M-D, Gordon MP, Sciaky D, Nester EW. 1977. Octopine and nopaline metabolism in Agrobacterium tumefaciens and crown gall tumor cells: role of plasmid genes. Journal of Bacteriology 129:101-107. 
1019

1020

1021

1022

1023

1024

1025

1026

1027

1028

1029

1030

1031

1032

1033

1034

1035

1036

1037

1038

1039

1040

1041

1042

1043

1044

1045

1046

1047

1048

1049

1050

1051

1052

1053

1054

1055

1056

1057

Moore, A. M., Patel, S., Forsberg, K. J., Wang, B., Bentley, G., Razia, Y., Qin, X., Phillip I.

Tarr, P.I., Gautam Dantas, G. 2013. Pediatric Fecal Microbiota Harbor Diverse and Novel Antibiotic Resistance Genes, PLoS One 8:e78822. DOI: 10.1371/journal.pone.0078822. eCollection 2013.

Mulcahy, L.R., Burns, J.L., Lory, S., and Lewis, K, 2010. Emergence of Pseudomonas aeruginosa atrains producing high levels of persister cells in patients with cystic fibrosis. J Bacteriol. 192:619. doi: 10.1128/JB.01651-09. Epub 2010 Oct 8. PMID: 20935098 Free PMC Article.

Mulcahy, L.R., Isabella, V.M., and Lewis, K. 2014. Pseudomonas aeruginosa biofilms in disease. Microb Ecol. 68:1. doi: 10.1007/s00248-013-0297-x. Epub 2013 Oct 6

Murphy PJ, Roberts WP. 1979. A Basis for Agrocin 84 sensitivity in Agrobacterium radiobacter. Journal of General Microbiology 114:207-221.

Nehme D, Poole K. 2005. Interaction of the MexA and MexB components of the MexAB-Opr Multidrug efflux system of Pseudomonas aeruginosa: identification of MexA extragenic suppressors of a T578I mutation in MexB. Antimicrobial Agents and Chemotherapy 49:43754378. DOI: 10.1128/AAC.49.10.4375-4378.2005

Nester, EW. 2015. Agrobacterium: nature's genetic engineer. Front Plant Sci. 2015 Jan 6;5:730. doi: 10.3389/fpls.2014.00730. eCollection 2014. PMID: 25610442 Free PMC Article

Nollmann FI, Dowling A, Kaiser M, Deckmann K, Grösch S, ffrench-Constant R, Bode HB. 2012. Synthesis of szentiamide, a depsipeptide from entomopathogenic Xenorhabdus szentirmaii with activity against Plasmodium falciparum Beilstein. Journal of Organic Chemistry 8:528533.

Nordmann P, Ronco E, Naas T, Duport C, Michel-Briand, Y. Labia R. 1993. Characterization of a novel extended-spectrum beta-lactamase from Pseudomonas aeruginosa. Antimicrobial Agents and Chemotherapy 37: 962-969. PMID: 8517722 PMCID: PMC187863

Ooms G, Klapwijk PM, Poulis JA, Schilperoort RA. 1980. Characterization of Tn904 insertions in octopine Ti-plasmid mutants of Agrobacterium tumefaciens. Journal of Bacteriology 144:8291.

Ooms G, Hooykaas PJJ, Moolenaar G, Schilperoort RA. 1981. Crown gall tumors of abnormal morphology, induced by Agrobacterium tumefaciens carrying mutated octopine Ti-plasmids: Analysis of T-DNA functions. Gene 14:33-50.

Ooms G, Hooykaas PJJ, Van Veen RJM, Van Beelen P, Regensburg-Tuink AJG, Schilperoort RA. 1982. Octopine Ti plasmid deletion mutants of Agrobacterium tumefaciens with emphasis on the right side of the T-region. Plasmid 7:15-29.

Otter, J. A., Doumith, M., Davies, F., Mookerjee, S., Dyakova, E., Gilchrist, M., Brannigan, E. T., Bamford, K., Galletly, T., Donaldson, H., Aanensen, D. M., Ellington, M. J., Hill, R., Turton, J. F., Hopkins, K. L., Woodford, N. Holmes, A. 2017. Emergence and clonal spread of colistin resistance due to multiple mutational mechanisms in carbapenemase-producing 
Klebsiella pneumoniae in London. Scientific Reports 7:12711. DOI: 10.1038/s41598-017-126374.

Ötvös, L. Jr. D. Wade, J. D. 2014. Current challenges in peptide-based drug discovery. Specialty Grand Challenge Article Frontiers in Chemistry 2, $62 . \mid$ https://doi.org/10.3389/fchem.2014.00062

Papp-Wallace KM1, Endimiani A, Taracila MA, Bonomo RA. 2011. Carbapenems: past, present, and future. Antimicrobial Agents and Chemotherapy 55:4943-4960. DOI: 10.1128/AAC.0029611. Epub 2011 Aug 22.

Park D., Ciezki K., van der Hoeven R., Singh S., Reimer D., Bode H.B., Forst S. 2009. Genetic analysis of xenocoumacin antibiotic production in the mutualistic bacterium Xenorhabdus nematophila. Molecular Microbiology 73:938-949. doi: 10.1111/j.1365-2958.2009.06817.x. Epub 2009 Aug 4.

Petit A, David C, Dahl GA, Ellis JG, Guyon P, Casse-Delbart F, Tempe J. 1982. Further extension of the opine concept: Plasmids in Agrobacterium rhizogenes cooperate for opine degradation. Molecular and General Genetics 190:204-214.

Pitout JD. 2008. Multiresistant Enterobacteriaceae: new threat of an old problem. Expert Review of Antimicrobial Infection Therapy 6:657-669. doi: 10.1586/14787210.6.5.657

Reimer D, Bode HB. 2014. A natural prodrug activation mechanism in the biosynthesis of nonribosomal peptides. Natural Products Report 31:154-159. doi: 0.1039/c3np70081j. Review. PMID: 24356302

Reverse-Phase Chromatography. RP-HPLC for peptides/ Sigma Technical Service 16-31.

Rice, L. B. 2008. Federal funding for the study of antimicrobial resistance in nosocomial pathogens: no ESKAPE. Journal of Infectious Diseases, 197(8):1079-1081. doi: 10.1086/533452 PMID: 18419525.

Rychlik, I., Karasova, D., Sebkova, A., Volf, J., Sisak, F., Havlickova, H., Kummer, V., Imre, A., Szmolka,A., Nagy, B. 2009. Virulence potential of five major pathogenicity islands (SPI-1 to SPI-5) of Salmonella enterica serovar Enteritidis for chickens. BMC Microbiol. 2009; 9: 268. Published online 2009 Dec 19. doi: 10.1186/1471-2180-9-268 PMCID: PMC2803193

Ryder MH, Tate ME, Jones GP. 1984. Agrocinopine A, a tumor-inducing plasmid-coded enzyme product, is a phosphodiester of sucrose and L-arabinose. Journal of Biological Chemistry 259:9704-9710.

Rzewuska M, Stefańska I, Kizerwetter-Świda MI, Chrobak M, Chimel D, Szczygielska P, Leśniak M, Binek M. 2015. Characterization of Extended-Spectrum- $\beta$-Lactamases Produced by Escherichia coli Strains Isolated from Dogs in Poland. Polish Journal of Microbiology 64: 285288.

Schechner V, Straus-Robinson K, Schwartz D, Pfeffer I, Tarabeia J, Moskovich R, Chmelnitsky I, Schwaber MJ, Carmeli Y, Navon-Venezia S. 2009. Evaluation of PCR-based 
testing for surveillance of KPC-producing carbapenem-resistant members of the Enterobacteriaceae family. Journal of Clinical Microbiology 47:3261-3265. DOI: 10.1128/JCM.02368-08. Epub 2009 Aug 12.

Schroder G, Klippt W, Hillebrand A, Ehring R, Koncz Cs, Schroder J. 1983. The conserved part of the T-region in Ti-plasmids expresses four proteins in bacteria. EMBO Journal 2:403-409.

Schwaber MJ1, Lev B, Israeli A, Solter E, Smollan G, Rubinovitch B, Shalit I, Carmeli Y; 2011. Israel Carbapenem-Resistant Enterobacteriaceae Working Group Containment of a country-wide outbreak of carbapenem-resistant Klebsiella pneumoniae in Israeli hospitals via a nationally implemented intervention. Clinical Infectious Diseases 52:848-855. DOI: 10.1093/cid/cir025. Epub 2011 Feb 11

Shi J, Mao NF, Wang L, Zhang HB, Chen Q, Liu H, Tang X, Jin T, Zhu CT, Li FB, Sun LH, Xu XM, Xu YQ 2014. Efficacy of combined vancomycin and fosfomycin against methicillinresistant Staphylococcus aureus in biofilms in vivo. PLoS One 9:e113133. DOI: 10.1371/journal.pone.0113133.

Slater SC, Goldman BS, Goodner B, Setubal JC, Farrand SK, Nester EW, Burr TJ, Banta L, Dickerman AW, Paulsen I, Otten L, Suen G, Welch R, Almeida NF, Arnold F, Burton OT, Du Z, Ewing A, Godsy E, Heisel S, Houmiel KL, Jhaveri J, Lu J, Miller NM, Norton S, Chen Q, Phoolcharoen W, Ohlin V, Ondrusek D, Pride N, Stricklin SL, Sun J, Wheeler C, Wilson L, Zhu, H, Wood DW. 2009. Genome sequences of three Agrobacterium biovars help elucidate the evolution of multichromosome genomes in bacteria. Journal of Bacteriology 191:2501-2511. DOI: 10.1128/JB.01779-08. Epub 2009 Feb 27.

Stockwell VO, Sundin GW. Jones AL. 2002. Antibiotic use in plant agriculture. Annual Review of Phytopathology 40:443-465.

Strateva T, Yordanov D. 2009. Pseudomonas aeruginosa - a phenomenon of bacterial resistance. Journal of Medical Microbiology 58:1133-1148. DOI: 10.1099/jmm.0.009142-0. Epub 2009 Jun 15.

Sun H, Wang H, Xu Y, Jones RN, Costello AJ, Liu Y, Li G, Chen M, Mendes RE 2012. Molecular characterization of vancomycin-resistant Enterococcus spp. clinical isolates recovered from hospitalized patients among several medical institutions in China. Diagnostic Microbiology and Infectious Disease 2012 Dec; 74(4):399-403. doi: 10.1016/j.diagmicrobio.2012.09.006. Epub 2012 Oct 23.PMID: 23099304

Szmolka A, Nagy B, 2013. Multidrug resistant commensal Escherichia coli in animals and its impact for public health. Search Results Frontiers in Microbiology. 4: Article 258, 1-13. Published online 2013 Sep 3. DOI: 10.3389/fmicb.2013.00258 PMCID: PMC3759790.

Talbot GH1, Bradley J, Edwards JE Jr, Gilbert D, Scheld M, Bartlett JG 2006. Bad bugs need drugs: an update on the development pipeline from the Antimicrobial Availability Task Force of the Infectious Diseases Society of America. Clinical Infectious Diseases Mar 1; 42:657-668. Epub 2005 Jan 25. 
1136

1137

1138

1139

1140

1141

1142

1143

1144

1145

1146

1147

1148

1149

1150

1151

1152

1153

1154

1155

1156

1157

1158

1159

1160

1161

1162

1163

1164

1165

1166

1167

1168

1169

1170

1171

Talbot G. H. 2008. What is in the pipeline for Gram-negative pathogens? Expert Review of Antiinfective Therapy 6:39-49. DOI: 10.1586/14787210.6.1.39. PubMed] [Cross Ref]; http://dx.doi.org/10.1586/14787210.6.1.39

Taylor CG, Fuchs B, Collier R, Lutke WK. 2006. Generation of composite plants using Agrobacterium rhizogenes. Methods in Molecular Biology 343:155-167. Review.

Temkin, E., Adler, A., Lerner, A. Carmeli, Y. 2014. Carbapenem-resistant Enterobacteriaceae: biology, epidemiology, and management. New York Academy of Sciences 1323:22-42. DOI: $10.1111 /$ nyas. 12537

Tenover FC, Sinner SW, Segal RE, Huang V, Alexandre SS, McGowan JE Jr, Weinstein MP 2009. Characterisation of a Staphylococcus aureus strain with progressive loss of susceptibility to vancomycin and daptomycin during therapy. International Journal of Antimicrobial Agents, Jun; 33(6):564-568. DOI: 10.1016/j.ijantimicag.2008. 12.010. Epub 2009 Feb 23.

Tomasz, A. 1998. Accelerated evolution: emergence of multidrug resistant gram-positive bacterial pathogens in the 1990's.Netherlands Journal of Medicine; 52:219-227

Tran TT, Munita JM, Arias CA. 2015. Mechanisms of drug resistance: daptomycin resistance. Annals of the New York Academy of Sciences 1354:32-53. DOI: 10.1111/nyas.12948. Epub 2015 Oct 23. Review. PMID: 26495887 Free PMC Article

Uraji M, Suzuki K, Yoshida K. 2002. A novel plasmid curing method using in-compatibility of plant pathogenic Ti plasmids in Agrobacterium tumefaciens. Genes and Genetic Systematics 77:1-9.

Vallenet D, Belda E, Calteau A, Cruveiller S, Engelen S, Lajus A, Le Fèvre F, Longin C, Mornico D, Roche D, Rouy Z, Salvignol G, Scarpelli C, Thil Smith AA, Weiman M, Médigue C. 2013. MicroScope - an integrated microbial resource for the curation and comparative analysis of genomic and metabolic data. Nucleic Acids Research 41:D636 -D647. DOI: $10.1093 /$ nar/gks1194

Van Larebeke N, Engler G, Holsters M, Van den Elsacker S, Zaenen I, Schilperoort RA, Schell J. 1974. Large plasmid in Agrobacterium tumefaciens essential for crown gall-inducing ability. Nature 252:169-170. (08 November 1974); DOI: 10 1038/252169a0

Vila J, Martí S, Sanchez-Céspedes J. 2007. Porins, efflux pumps and multidrug resistance in Acinetobacter baumanii. Journal of Antimicrobial Chemotherapy 59:1210-1215. Epub 2007 Feb 26.

Vivas EI, Goodrich-Blair H. 2001. Xenorhabdus nematophilus as a model for host-bacterium interactions: rpoS is necessary for mutualism with nematodes. Journal of Bacteriology 183:4687-4693.

Vozik D, Bélafi-Bakó K, Hevesi M, Böszörményi E, Fodor A. 2015. Effectiveness of a peptiderich fraction from Xenorhabdus budapestensis culture against fire blight disease on apple 
blossoms. Notulae Botanicae Horti Agrobotanici Cluj-Napoca 43:547-553. DOI: 10.15835/nbha4329997, Available online: www.notulaebotanicae.ro

Völgyi A, Fodor A, Forst S. 2000. Inactivation of a novel gene produces a phenotypic variant cell and affects the symbiotic behavior of Xenorhabdus nematophilus. Applied and Environmental Microbiology. 66:1622-1628.PMID: 10742251 Free PMC Article

Wiegand I, Hilpert K, Hancock RE. 2008. Agar and broth dilution methods to determine the minimal inhibitory concentration (MIC) of antimicrobial substances. Natural Protocol 3:163175. doi: 10.1038/nprot.2007.521.PMID: 18274517

White FF, Nester EW. 1980. Relationship of plasmids responsible for hairy root and crown gall tumorigenicity. Journal of Bacteriology 144:710-720.

Wiegand I, Hilpert K, Hancock RE. 2008. Agar and broth dilution methods to determine the minimal inhibitory concentration (MIC) of antimicrobial substances. Nature Protocols 3:163175. doi: 10.1038/nprot.2007.521. PMID: 18274517

Williamson R, Calderwood SB, Moellering RC Jr, Tomasz A. 1983. Studies on the mechanism of intrinsic resistance to beta-lactam antibiotics in group D streptococci. Journal of General Microbiology 129:813-822.

Wise AA, Liu Z, Binns AN. 2006. Culture and maintenance of Agrobacterium strains. Methods in Molecular Biology 343:3-14. Review.

Wright TH, Bower BJ, Chalker JM, Bernardes GJL, Wiewiora R, Ng W-L, Raj R, Faulkner SM, Vallée RJ, Phanumartwiwath A, Coleman OD, Thézénas M-L, Khan M, Sébastien RG, Galan SRG, Lercher L, Schombs MW, Gerstberger S, Palm-Espling ME, Baldwin AJ, Kessler BD, Claridge TDW, Mohammed S, Davis BG. 2016. Posttranslational mutagenesis: A chemical strategy for exploring protein side-chain diversity. Science 354:597-610.

Wood DW, Setubal JC, Kaul R, Monks DE, Kitajima J, Vagner P, Okura K, Zhou Y, Chen L, Wood GE, Almeida NF Jr., Woo L, Chen Y, Paulsen IT, Eisen JA, Karp PD, Bovee D, Sr., Chapman P, Clendenning J, Deatherage G, Gillet W, Grant C, Kutyavin T, Levy R, Li MJ, McClelland E, Palmieri A, Raymond C, Rouse G, Saenphimmachak C, Wu Z, Romero P, Gordon D, Zhang S, Yoo H, Tao Y, Biddle P, Jung M, Krespan W, Perry M, GordonKamm B, Liao L, Kim S, Hendrick C, Zhao Z-Y, Dola M, Chumley F, Tingey SV, Tomb JF, Gordon MP, Olson MV, Nester EW. 2001. The genome of the natural genetic engineer Agrobacterium tumefaciensC58. Science 294:2317-2323. DOI: 10.1126/science.1066804

Xiao Y, Meng F, Qiu D, Yang X. 2012. Two novel antimicrobial peptides purified from the symbiotic bacteria Xenorhabdus budapestensis NMC-10. Peptides 35:253-260. http://dx.doi.org/10.1016/j.peptides.2012.03.027

Załuga J, Stragier P, Baeyen S, Haegeman A, Van Vaerenbergh J, Maes M, De Vos P. 2014. Comparative genome analysis of pathogenic and non-pathogenic Clavibacter strains reveals adaptations to their lifestyle. BMC Genomics 15: 392- 406 DOI: 10.1186/1471-2164-15-392. PMCID: PMC4059874 
Figure 1 (on next page)

Effects of EMA_PF2 on Xenorhabdus end E. coli strains: OD values determined in in vitro liquid bioassays

X. nematophila HGB1795 is extremely sensitive to EMA_PF2. (A) Comparison of the OD values of HGB1795 and positive (E.coli HGB2226 and HGB1333) and positive ( $X$. budapestensis HGB2838 and $X$. szentirmaii HGB1839) control strains treated with different doses of EMA_PF2. (B) Comparison of the OD values of HGB1795 with those of its parental strains deposited in Madison (USA) and Germany. For more details, see Caption to Fig 1. 


\section{Antimicrobial Activity of EMA_PF2 on E. coli and Xenorhabdus strains. Results of Liquid Culture Bioassays}
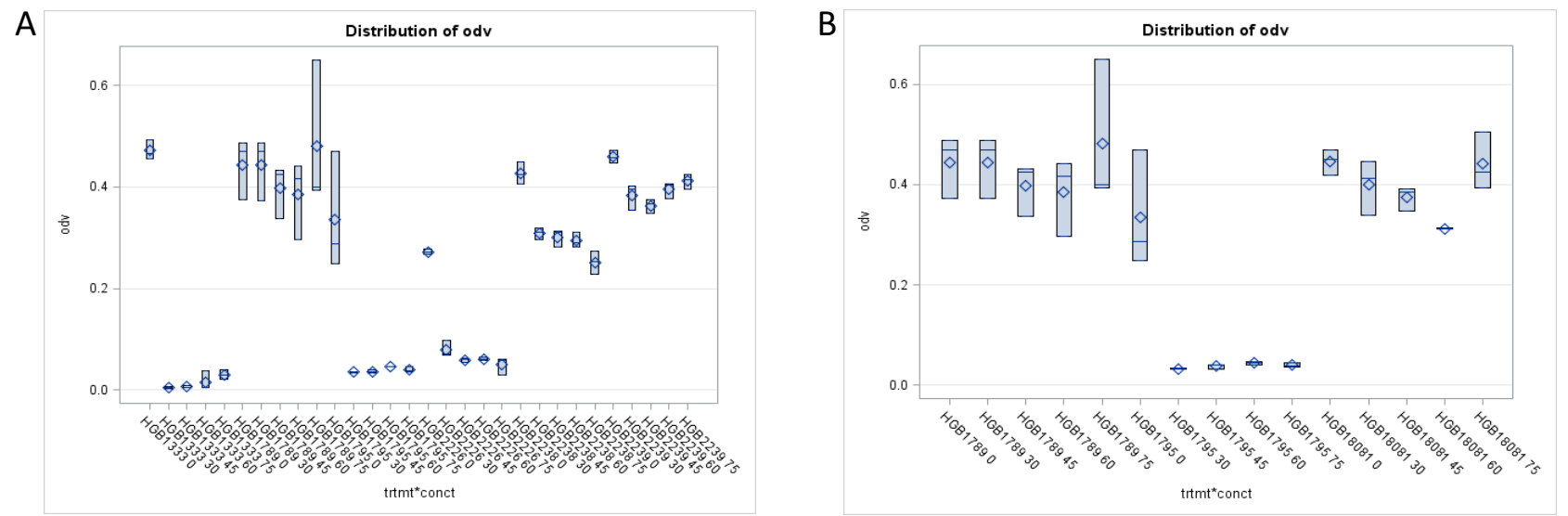

In Fig $1 \mathrm{~A}$ the distribution of the OD values (Means +/- StDev) measured in 24-h cultures of Escherichia coli (strains HGB1333 and HGB2226, grown at $37^{\circ} \mathrm{C}$ ) and those of Xenorhabdus budapestensis (HG2338), X. szentirmaii (HGB2339) and $X$. nematophila HGB1789 wild type strains (grown at $28{ }^{\circ} \mathrm{C}$ ) demonstrate the strong anti-Gram-Negative activity of the antimicrobial peptide fraction EMA_PF2 isolated from the cell-free-culture of $X$. budapestensis (HGB033) against which not only the cells of the EMA-producing species, $X$. budapestensis, but those the wild-type strains of $X$. szentirmaii and $X$. nematophila cells are completely protected. (Not all data are given, but each tested $X$. nematophila strains, including $X$. nematophila Types Strain ATTC 19061 deposited in Madison as well, as HGB800; and var-1 (Völgyi, Fodor and Forst, 2002); all tested lrp mutants characteristically resembling to secondary form strains (Cowles et al., 2007) were unambiguously resistant to EMA_PF2, Fodor et al., unpublished). Strain HGB1795, however, which had been isolated as a Tn insertion mutant from the spontaneous rifampicin resistant $X$. nematophila strain HGB081 (of H. Goodrich - Blair, a spontaneous mutant a derivative of $X$. nematophila Types Strain ATTC 19061, see Materials and Methods) proved as sensitive as the examined $E$. coli strains. To confirm this interesting discovery, we repeated the test in an independent experiment, in which HGB1795 was treated with another preparation of EMA_PF2, in comparison with the original HGB081 deposited in the laboratory of Prof. H. Goodrich-Blair and that clone of this mutant from which H. Bode isolated a transposon-induced insertion mutant of the XNC1_2022 gene what was then deposited in the Laboratory of H. GoodrichBlair in Madison, WI as HGB1795, see data on Fig 1 B.

Abbreviations: Abscissa, trmt*conc: 0, 30, 45, 60 and $75 \mu \mathrm{g} / \mathrm{ml}$ EMA_PF2; $10081=X$. nematophila spontaneous rifampicin resistant parental strain HGB081; $1789=X$. nematophila strain HGB1789, a clone of HGB081; the parental strain of HGB1795; HGB1795= transposon-induced insertion mutant of the XNC1_2022 gene isolated from HGB1789 (HGB081); HGB 1333 and HGB2226 = E. coli (negative control) strains; HGB2238 and HGB2239: spontaneous rifampicin-resistant (positive control) strains isolated from Xenorhabdus budapestensis HGB033 and X. szentirmaii HGB036 by A. Fodor; $o d v=$ optical density of the respective bacterium culture

These (Fulbright-sponsored) experiments were carried out in the Laboratory of Professor Heidi Goodrich-Blair using her equipment (spectrophotometers and other things) and bacterium strains, at Department of Bacteriology, University of Madison, Linden Drive, Madison WI, and the USA. 
Figure 2 (on next page)

HPLC profile of EMA_PF2

Off the fractions collected from below the three large peaks only those exerted detectable (strong) antimicrobial activities which were collected from below A2. For more details, see Caption to Fig 2. 


\section{High Pressure Liquid Chromatogram (HPLC) Profile EMA_PF2.}

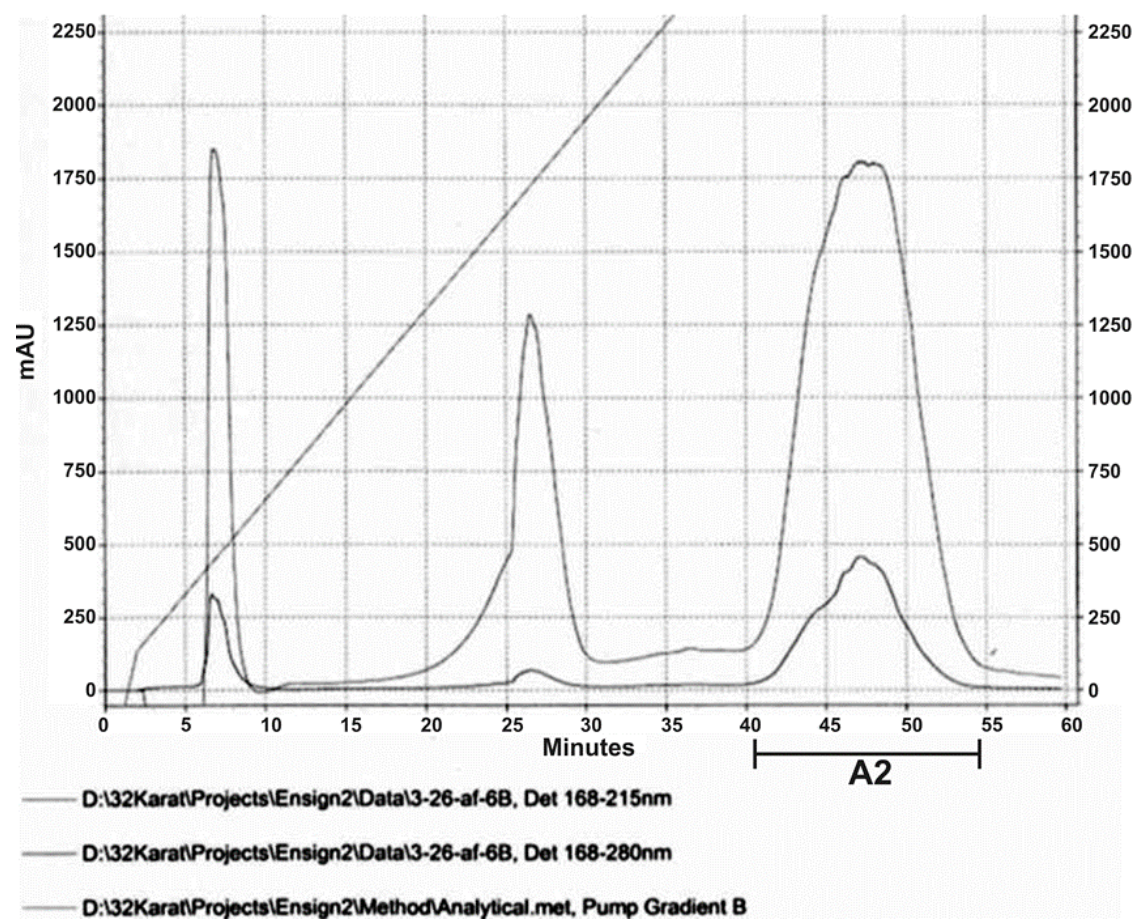

EMA_PF2 is peptide- fraction (EMA_PF2), which had been isolated from cell-free culture media (CFCM) of $X$. budapestensis (EMA) by Amberlite XAD1148® adsorption; purified followed by gradient $\mathrm{MeOH}$ elution; and eluted by with $99 \mathrm{~V} / \mathrm{V} \%$ of methanol, followed by sterile ultrafiltration (Vozik et al., 2015). HPLC peaks were detected at $168-215 \mathrm{~nm}$ and 168-280nm, respectively. When tested in Agar Diffusion Bioassays Fractions collected from below the third (A2) peak (between 40-45 min intervals) exerted strong antimicrobial activities on both Gram-positive (Staphylococcus aureus, strain JE) and Gram-negative (Escherichia coli strain HGB2226) test organisms, (see Table 2) and also on Candida albicans (not shown). Fractions collected from below the peaks at the first B2, (5-10 min), and the second, B1. (18-30 min) intervals showed no antimicrobial activity on either target. This experiment was carried out in the Laboratory of Professor Emeritus Jerald C. Ensign using his equipment, solutions and standard methods, Department of Bacteriology, University of Madison, Linden Drive, Madison WI, and the USA. Maldi analysis of the most active fraction pooled samples from below the A2 peak three peaks are presented in Fig $3 \mathrm{~A}$. 
Figure 3 (on next page)

MALDI profiles of two antimicrobial peptide complexes obtained from EMA cell-free culture media by different protocols.

(A) MALDI profile of pooled antimicrobial fractions from below A2 peak of the HPLC profile of EMA_PF2. (B) MALDI profile of EMA 30, purified by RPLC. For more details, see Caption to Fig 3. 


\section{Comparison of the MALDI profiles of two antimicrobial active preparations from the cell- free culture medium (CFCM) of Xenorhabdus budapestensis (EMA).}

A

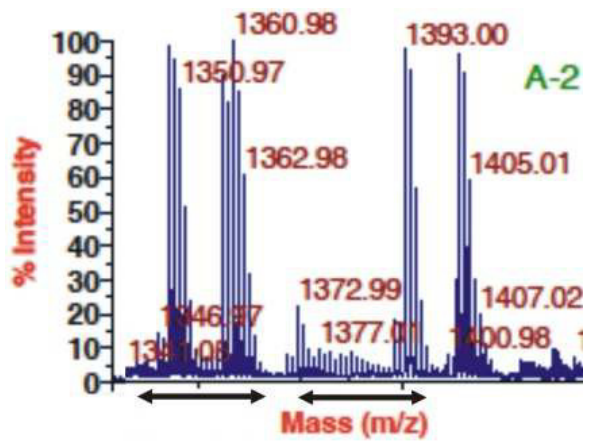

B

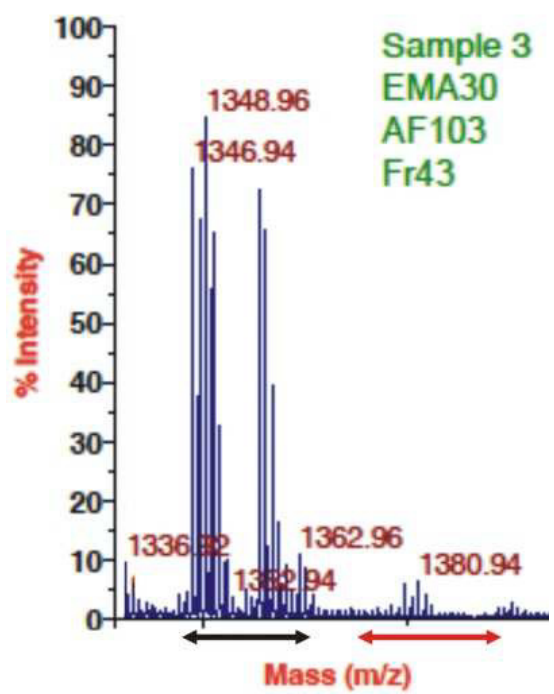

The complete MALDI profile of the pooled fractions from below A2 peak of the HPLC chromatogram (Fig 2) of the Amberlite-Adsorbed, MeOH-purified EMA_PF2 at three magnifications (not shown)

Each peptide-peak is $<2,200 \mathrm{~m} / \mathrm{Z}$. There are many peaks in $\mathrm{m} / \mathrm{Z}$ range, where Bicornutin $\mathrm{A}$ is expected to be present (500-1000) and the there are many in the $\mathrm{m} / \mathrm{Z}$ range of 1,200-1500, (lowermost chromatogram); but the majority are located between 1,300-1,400 (uppermost diagram). Fig 3A shows this region in more details. Two arrows indicate the most densely populated sub-regions.

The HPLC profile of purified peptide preparation obtained by column chromatography (EMA30, (AF103), is very similar (not shown). The MALDI profile of the most active antimicrobial HPLC fraction, Fr43 of EMA30 (AF103) is rather similar (Fig 3B) but not identical to that of A2.

The main difference is that only the left sub-region of the $\mathrm{m} / \mathrm{Z}$ range on Fig $3 \mathrm{C}$ has peptide peaks, the right one, labelled with red arrow is almost empty. The left molecular-region is where fabclavine isomers (Fuchs et al., 2012, 2014 ) are expected to be located, and this region is very similar on Fig $3 \mathrm{~B}$ and $3 \mathrm{C}$. The $\mathrm{m} / \mathrm{Z}$ regions were Bicornutin $\mathrm{A}$ is expected to be localized is very similar in $3 \mathrm{~B}$ and $3 \mathrm{C}$. This observation may be considered as an indirect confirmation that the predominant active antimicrobial peptide component of EMA AMP complexes is the fabclavine, but Bicornutin A (or similar peptides in other Xenorhabdus species, with of unknown role) may also be present in antimicrobial active bio-preparations. 


\section{Figure 4 (on next page)}

Comparison of the antimicrobial activity of peptide fractions separated from HPLC from EMA(30) on 4 different targets in Agar Diffusion Bioassays

Test organisms: SA = S. aureus JE; as a Gram-positive; EC= E. coli HGB2226; as a Gramnegative target; $\mathrm{CA}=$ Candida albicans JE, as fungal target; HGB1795: an insertion mutant of $X$. nematophila with extreme sensitivity to Xenorhabdus antimicrobials. Columns of holes: the places into which $0.1 \mathrm{ml}$ of samples were pipetted. from left to right: sample collected in the 19th, 21st, 23rd, 25th, 40th, 43rd, 44th, 45th, 49th and 57th min of HPLC run. For more details, see Caption to Fig 4. 


\title{
Growth inhibiting activities of AF_103 (EMA30) HPLC fractions on different targets in Agar-Diffusion tests
}

\author{
Candida \\ albicans (JE) \\ Staphylococcus \\ aureus (JE) \\ E. coli \\ HGB1226 \\ $X$. nematophila \\ (HGB 1795)
}

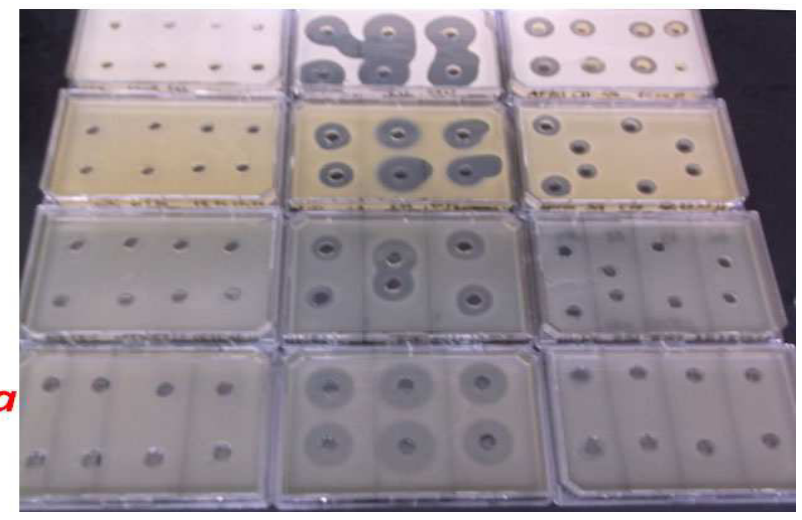

Each hole had been filled with $100 \mu \mathrm{l}$ volume of a sample, overlaid with the uniformly soft-agar diluted cellsuspension of the respective test organism. Samples (holes) from left to right Left plates: fractions collected at retention time $19^{\text {th }}, 21^{\text {st }}, 23^{\text {rd }}$ and $25^{\text {th }}$ from below the first peak of HPLC run (Fig. 1), Plates in the middle: fractions collected at the $40^{\text {th }}, 43^{\text {rd }}$ and the $44^{\text {th }}$ minutes retention times; from below the largest sharp peak of HPLC run, Right plates: fractions collected at the $45^{\text {th }}, 47^{\text {th }}, 53^{\text {rd }}$ and $57^{\text {th }}$ minutes from below the last large, not-very-sharp peak (at the end of the chromatogram). From top to bottom: Sensitive test organisms: CA =Candida albicans, SA $=$ Staphylococcus aureus, EC =Escherichia coli HGB2226, X. nematophila HGB 1795, two replicates of each. 


\section{Table $\mathbf{1}$ (on next page)}

\section{Agrobacterium strains used in this study}

Genotype: includes genome that is the respective chromosome (C58; Ach5) with genome-selective markers; and the Plasmon (including the $\mathbf{T i}(\mathbf{R I})$ plasmid with plasmid/selective markers and the respective binary vector(BIN) with binary vector selective markers). The binary vectors are engineered DNA constructions which are capable to replicate in both Agrobacterium and E. coli cells and could be transmitted to plant cell as well because they include T-DNA border sequences which could be recognized by the respective vir gene product. Abbreviations of the selective markers : Nal ${ }^{\circledR}, \operatorname{Rif}{ }^{\circledR}$; Carb ${ }^{\circledR}$; $\mathbf{G e}{ }^{\circledR}$, and $\mathbf{S m}{ }^{\circledR}$ : resistant to naladixic acid, rifampicin, carbenicillin, gentamycin, and streptomycin, respectively. T-DNA: a special segment (cassette) of the Ti (RI) plasmid which could covalently be inserted into the infected plant chromosome. It carries genes expressed and regulated in the infected plant cell.

T-DNA ${ }^{(+)}$: genotype of the wild-type Ti plasmid having the intact T-DNA cassette;( $\boldsymbol{\Delta}$-T-DNA) means: [TDNA $]^{(-)}$genotype of the disarmed (non-virulent, helper) Ti (RI) plasmid from which the T-DNA cassette had been precisely excised. Opine: opines are strain-specific compounds, synthesized by the respective opinesynthase gene in the plant tumors and can also be catabolized by decomposing enzymes encoded in the respective Ti (RI) plasmid, located outside of the T-DNA cassette For more details: see Captive to Table 1). 
1 Table 1: Agrobacterium tumefaciens strains used in this study

2

\begin{tabular}{|c|c|c|c|c|c|c|c|}
\hline \multicolumn{8}{|c|}{ Agrobacterium strain } \\
\hline \multicolumn{2}{|c|}{ Name } & \multicolumn{4}{|c|}{ Genotype } & \multirow{3}{*}{ T-DNA } & \multirow{3}{*}{ Opine } \\
\hline \multirow[b]{2}{*}{ LAB } & \multirow[b]{2}{*}{ REF } & \multicolumn{2}{|c|}{ Genome } & \multicolumn{2}{|c|}{ Plasmon } & & \\
\hline & & $\begin{array}{c}\text { Chromo } \\
\text { some }\end{array}$ & $\begin{array}{c}\text { Selective } \\
\text { marker }\end{array}$ & Ti plasmid & BIN & & \\
\hline HP1836 & C58C*NOP1 & C58C* & $\mathrm{Nal}^{\mathrm{R}}$ & Cured & & {$[\text { T-DNA }]^{(-)}$} & NOP \\
\hline HP1840 & C58C*NOP2 & C58C* & $\mathrm{Nal}^{\mathrm{R}}$ & Cured & & {$\left[\right.$ T-DNA] $^{(-)}$} & NOP \\
\hline HP1843 & C58C*NOP3 & C58C* & $\mathrm{Nal}^{\mathrm{R}}$ & Cured & & {$\left[\right.$ T-DNA] $^{(-)}$} & NOP \\
\hline HP1841 & C58C1NOP4 & C58C1* & Rif $^{\mathrm{R}}$ & Cured & & [T-DNA] $^{(-)}$ & NOP \\
\hline HP1842 & C58C1NOP5 & C58C1* & Rif $^{R}$ & Cured & & {$\left[\right.$ T-DNA $^{(-)}$} & NOP \\
\hline SZL4 & $\begin{array}{r}\text { C58C1/ } \\
\text { pMP90NOP6 }\end{array}$ & $\mathrm{C} 58 \mathrm{C} 1 *$ & $\operatorname{Rif}^{\mathrm{R}}$ & pMP90 Ge ${ }^{R}$ & $\begin{array}{l}\text { pHP9- } \\
\text { Gus101 }\end{array}$ & $\Delta-[\mathrm{T}-\mathrm{DNA}]$ & NOP \\
\hline HP1837 & $\begin{array}{r}\text { LBA4404/0 } \\
\text { OCT1 }\end{array}$ & Ach5 & $\operatorname{Rif}^{R}$ & pAl4404 Sm & & $\Delta-[$ T-DNA $]$ & OCT \\
\hline SZL2 & $\begin{array}{r}\text { LBA } 4404 / \\
\text { pBIN-OCT2 } \\
\end{array}$ & Ach5 & $\operatorname{Rif}^{\mathrm{R}}$ & pAl4404 $\mathrm{Sm}^{\mathrm{R}}$ & $\mathrm{pBIN}$ & $\Delta-[$ T-DNA] & OCT \\
\hline HP1838 & A281 & C58 & $\operatorname{Rif}^{\mathrm{R}}$ & $\begin{array}{c}\text { pTiA136 } \\
\text { Bo542 }\end{array}$ & & {$[\text { T-DNA }]^{(+)}$} & AGR \\
\hline HP1839 & AGL1 & $\begin{array}{l}\text { C58C* } \\
\text { (AG0) }\end{array}$ & $\begin{array}{c}\mathrm{Ca}^{\mathrm{R}} \\
\mathrm{RecA}^{(-)}\end{array}$ & $\mathrm{pEHA} 101 \mathrm{Nal}^{\mathrm{R}}$ & & $\Delta-[\mathrm{T}-\mathrm{DNA}]$ & AGR \\
\hline SZL1 & EHA 105 & C58C* & $\operatorname{Rif}^{\mathrm{R}}$ & pEHA105Nal ${ }^{R}$ & & $\Delta-[\mathrm{T}-\mathrm{DNA}]$ & AGR \\
\hline SZL3 & $\mathrm{A} 4 \mathrm{~T}$ & & $\operatorname{Rif}^{\mathrm{R}}$ & A4T & & $\Delta-$ [T-DNA] & AGR \\
\hline
\end{tabular}

3 


\section{Captive / Footnotes to Table1 Agrobacterium tumefaciens strains used in this study.}

Genotype: includes genome that is the respective chromosome (C58; Ach5) with genomeselective markers; and the Plasmon (including the respective Ti (RI) plasmid with plasmid/selective markers and the respective binary vector (BIN) with binary vector selective markers). The binary vectors are engineered DNA constructions which are capable to replicate in both Agrobacterium and E. coli cells and could be transmitted to plant cell as well because they include T-DNA border sequences which could be recognized by the respective vir gene product.

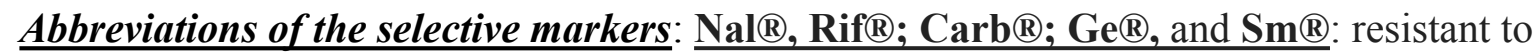
naladixic acid, rifampicin, carbenicillin, gentamycin, and streptomycin, respectively.

T-DNA: a special segment (cassette) of the Ti (RI) plasmid which could covalently be inserted into the infected plant chromosome. It carries genes expressed and regulated in the infected plant cell. T-DNA ${ }^{(+)}$: genotype of the wild-type Ti plasmid having the intact T-DNA cassette; $(\boldsymbol{\Delta}-\mathbf{T}$ DNA) means: [T-DNA ${ }^{(-)}$genotype of the disarmed (non-virulent, helper) Ti (RI) plasmid from which the T-DNA cassette had been precisely excised. Opine: opines are strain-specific compounds, synthesized by the respective opine-synthase gene in the plant tumors and can also be catabolized by decomposing enzymes encoded in the respective Ti (RI) plasmid, located outside of the T-DNA cassette.

Abbreviations of opines: NOP =nopaline catabolizing (and synthetizing) Agrobacterium strain; OCT = octopine catabolizing (and synthetizing) Agrobacterium strain; AGR=agropine and L, L, - succinamopine catabolizing (and synthetizing) Agrobacterium strain.

Abbreviations of strains from which the complete Ti $(R I)$ plasmid had been removed: The C58 strains cured for the pTiC58 plasmid general C58C* means C58 cured. The C58 strains cured especially for the pTiC58 (rifR) Ti plasmid are labeled as C58C1. C58C1 means that the cured stain carries a chromosomal rifampicin resistance mutation. C58C1RifR was alternatively designated as GV3101. $\mathbf{C 5 8 C} *=$ (in this study) the cured stain carries a chromosomal naladixic acid resistance mutation. We did not have a chance to work on plasmidcured OCT and AGR strains.

For details on plasmids (pMP90; pA14404; pTiA136Bo542; pEHA101; pEHA105 and A4T) see text and Supplementary material TextS1. 


\section{Table 2 (on next page)}

Agar-diffusion bio-assays of antimicrobial active peptide fractions from EMA_CFCM on four sensitives targets

EMA_PF1, EMA_PF2, (both purified by Amberlite adsorption) and EMA 30, obtained by RPLC) proved extreme active. Both EMA_PF2 and EMA30 could be further be purified by HPLC, but EMA_PF2 lost its anti-Gram(+) and Gram(-) activities during further purification by RPLC. For more details, see the captive. 
2 Table 2 Agar-Diffusion Bioassays of Antimicrobial Activities of Peptide Fractions Isolated from 3 EMA CFCM: Inactivation Zone Sizes (IZ values) Determined in Four Targets Agar-Diffusion 4 test.

\begin{tabular}{|c|c|c|c|c|}
\hline \multirow{4}{*}{$\begin{array}{l}\text { Antimicrobial active } \\
\text { peptide preparation }\end{array}$} & \multicolumn{4}{|c|}{ Inactivation zone in $\mathrm{mm}^{2}$} \\
\hline & \multicolumn{4}{|c|}{ Gram negative targets } \\
\hline & \multicolumn{2}{|r|}{ HGB2226 } & \multicolumn{2}{|c|}{ HGB1795 } \\
\hline & $\mathrm{N}$ & Mean \pm SD & $\mathrm{N}$ & Mean +/- SD \\
\hline EMA_PF1 & 3 & $3820.00 \pm 690.22$ & 3 & $4280.00 \pm 415.69$ \\
\hline EMA_PF2 & 4 & $3683.75 \pm 799.23$ & 2 & 6602.50456 .08 \\
\hline EMA_PF2*20 & & 0.00 & 3 & $3370.00 \pm 635.83$ \\
\hline EMA_PF2*30 & & 0.00 & & $3119.00 \pm 842.61$ \\
\hline EMA_PF2*40 & & 0.00 & & $4088.00 \pm 678.70$ \\
\hline EMA_PF2*50 & & 0.00 & & $3821.67 \pm 214.20$ \\
\hline EMA_PF2*70 & & 0.00 & & $4640.00 \pm 850.97$ \\
\hline EMA_PF2*TF & & 0.00 & & $4172.00 \pm 1502.02$ \\
\hline EMA_(RPLC) $)_{30}$ & 3 & $1452.50 \pm 95.45$ & 3 & $1761.33 \pm 173.78$ \\
\hline AF103_(EMA)_HPLC40 & 3 & $617.00 \pm 88.02$ & 3 & $1135.33 \pm 119.52$ \\
\hline AF103_(EMA)_HPLC43 & 3 & $1614.00 \pm 81.41$ & 3 & $2073.33 \pm 244.32$ \\
\hline \multirow[t]{3}{*}{ AF103_(EMA)_HPLC44 } & 3 & $1019.33 \pm 113.52$ & 3 & $1385.00 \pm 100.00$ \\
\hline & \multicolumn{2}{|r|}{ SA } & \multicolumn{2}{|r|}{ CA } \\
\hline & $\mathrm{N}$ & Mean \pm SD & $\mathrm{N}$ & Mean \pm SD \\
\hline EMA_PF1 & 3 & $8723.33 \pm 600.44$ & 3 & $11746.67 \pm 704.37$ \\
\hline EMA_PF2 & 3 & $5931.67 \pm 453.22$ & 3 & $6291.6667 \pm 627.58134$ \\
\hline EMA_PF2*20 & & 0.00 & 1 & $530.00 \pm 0.00$ \\
\hline EMA_PF2*30 & & 0.00 & 3 & $696.33 \pm 279.69$ \\
\hline EMA_PF2*40 & & 0.00 & 3 & $544.67 \pm 226.68$ \\
\hline EMA_PF2*50 & & 0.00 & & 0.00 \\
\hline EMA_PF2*70 & & 0.00 & 3 & $623.33 \pm 175.65$ \\
\hline EMA_PF2*TF & & 0.00 & & $558.33 \pm 49.07$ \\
\hline EMA_(RPLC) $)_{30}$ & 3 & $1656.67 \pm 40.41$ & 3 & $1526.00 \pm 233.83$ \\
\hline AF103_(EMA)_HPLC40 & 3 & $1614.00 \pm 81.41$ & 3 & $2289.00 \pm 0.000$ \\
\hline AF103_(EMA)_HPLC43 & 3 & $1886.33 \pm 66.97$ & 3 & $2930.00 \pm 287.51$ \\
\hline AF103_(EMA)_HPLC44 & 3 & $1613.67 \pm 81.98$ & 3 & $2834.33 \pm 377.57$ \\
\hline
\end{tabular}


8 Captive / Footnotes to Table 2: Agar-Diffusion Bioassays of Antimicrobial Activities of 9 Peptide Fractions Isolated from EMA CFCM: Inactivation Zone Sizes (IZ values) Determined in 10 Four Targets Agar-Diffusion test.

Antimicrobial Activities of Peptide Fractions Isolated from EMA CFCM were determined in four targets in Agar-Diffusion test. Inactivation zones were calculated from the diameter of inactivation zone in 1-cm tick LBA plates and given in $\mathrm{mm}^{3}$.

\section{Abbreviations:}

\section{AMP Fractions:}

EMA_PF1: A peptide fraction isolated from the cell-free culture medium (CFCM) of Xenorhabdus budapestensis (EMA). EMA_PF1is a fraction supposed to be containing molecules of MW $>10,000 \mathrm{D}$. We suppose that the large peptides of PF1 this fraction adsorbed the smaller active peptides and we detected the activity of the complex rather than antimicrobial activity of peptides of MW > 10,000 D.

EMA_PF2 (PF2) consists of peptides of MW < 10,000 D;

EMA_PF2 $* 20$, EMA_PF2*30, EMA_PF2*40, EMA_PF2*50 and EMA_PF2*70: EMA_PF2 was further fractionated by, RPLC, and fractions eluted by $20.30,40,50$ and $70 \mathrm{~V} / \mathrm{V} \%$ of $\overline{\mathrm{AN}}$ containing $0.1 \%$ TFA, freeze-dried, taken up by PBS and bio-assayed. TF: fraction which did not adsorb to the column.

EMA_ (RPLC) 30 or (EMA30) also mentioned as AF103 (as HPLC sample) is a purified fraction of EMA PF by Reverse Phase Column Chromatography; eluted with $30 \mathrm{~V} / \mathrm{V} \%$ AN. (This was the only RPLC fraction active on Gram-negative targets). AF103_(EMA)_HPLC40, AF103_(EMA)_HPLC43 and AF103_(EMA)_HPLC44 HPLC sub-fractions of EMA30 (AF103) collected in the $40^{\text {th }}, 43^{\text {rd }}$, and $44^{\text {th }}$ minute of the run of sample AF103.

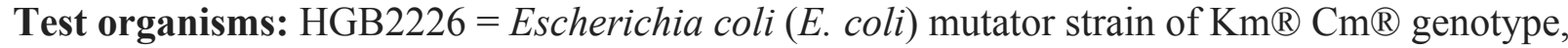
constructed by us (as a Gram-negative target); HGB1795 = a transposon-induced insertion mutant of the XNC1_2022 gene (Gene ID: 9430524; Gene Page Link: NCBI UniProtKB; Locus Tag: XNC1_2022 see gene page for GenePage for the XNC1_2022 gene EcoGene-RefSeq) from Xenorhabdus nematophila (strain ATCC 19061 / DSM 3370 / LMG 1036 / NCIB 9965 / AN6), kindly provided by Prof. Helge Bode, via Prof. Heidi Goodrich-Blair, which behaves like an immune-suppressed X. nematophila, a Xenorhabdus-antibiotic-sensitive Xenorhabdus mutant; $\mathrm{SA}=$ Staphylococcus aureus (as a Gram-positive), $\mathrm{CA}=$ Candida albicans as fungal target, respectively. 
Figure 5 (on next page)

Distribution of the OD values measured in in vitro liquid bioassays of EMA_PF2 in 12 Agrobacterium strains

Note that (the gross) MIC values could be determined only for 4 Agrobacterium strains, HP1837, H1839, A4T and EHA105, not for the others. Each of the sensitive ones is $\triangle$-TDNA strain. All the others should be considered as resistant ones but in different degree. For more details, see Captive o Fig 5. For raw data see Supplement. 


\section{Summary of the results of the in vitro liquid bioassays of EMA_PF2 in Agrobacterium strains of different genotype, opine type and Ti plasmid state.}

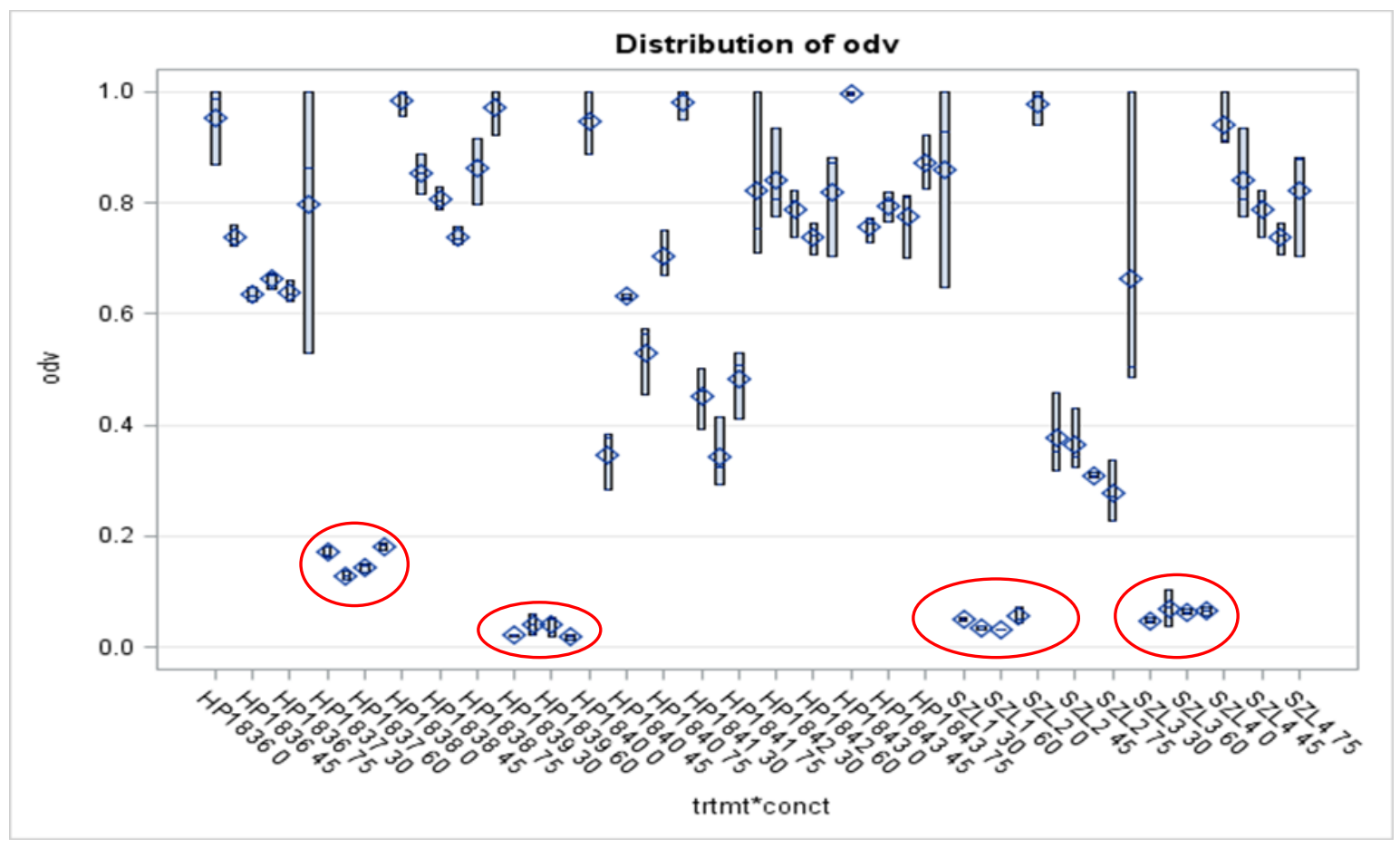

The mean values and standard deviations of OD $(o d v)$ were obtained from 3 replicates. $\mathrm{L}$ istribution of the OD values measured in 24h liquid cultures of 0,30,45, 60 and $75 \mu \mathrm{g} / \mathrm{ml}$ dose of EMA_PF2. The odv of each strain (HP1836; HP1837; HP1838; HP1839; HP1840; HP1841; HP1842; HP1843; SZL1; SZL2; SZL3; SZL4) were determined at each concentration. Because of space limit, not all data are noted on the abscissa. Data were analyzed by ANOVA procedure. Abbreviations: Odv = values of optical density (OD) determined spectroscopically, trmt*conct: ANOVA results of the strain (treatment) and dose (concentration) interaction (*); which is hardly different from those of the freshly inoculated LB culture controls. These four data groups of OD values are of those of the 30 and $60 \mu \mathrm{g} / \mathrm{ml} \mathrm{dose}$ of EMA PF treated HP1837; HP1839; SZL1 and SZL3 cultures, respectively. These Agrobacterium strains are considered to be of S phenotype (sensitive to EMA PF), while the rest of the strains are R phenotype (resistant to EM A PF), even if they are not uniformly resistant. 
Figure 6 (on next page)

Comparison of the sensitivities of the wild-type, virulent (A281) and a T-DNA deleted ( $\Delta$ -TDNA) derivative (EHA105), detected in Agar Diffusion Bioassay. Both of them are L, L,succinamopine, AGR) - catabolizing Agrobacterium strains.

A: EHA105; B: A281. Both of them are L, L,-succinamopine, AGR) - catabolizing Agrobacterium strains. Inactivation zones around the holes in the LB-Agar plates, containing $0.1 \mathrm{ml}$ volume of samples of EMA_PF2. 
Agardfiffusion bioassay of sterile cell-free culture medium (CFCM) of nematode-symbiotic bacterium Xenorhabdus budapesensis (EMA) on agropine—catabolizing (L,L,-succinamoipine utilizing, AGR) Agrobacterium tumefaciens strains.

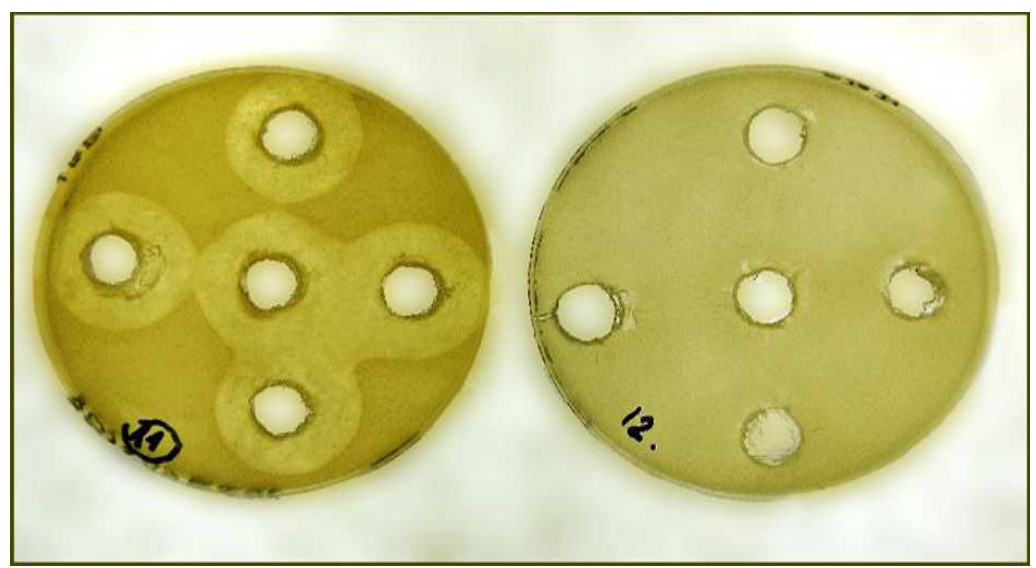

Left: EHA105, a T-DNA deleted ( $\triangle$-T-DNA) strain. Right: A281, the virulent, wild-type (T-DNA $(+)$ strain. Plasmid genotypes: EHA 105 (pTiBo542 (T-LNA(-) $=\left(\right.$ pEHA105); $\left.\mathrm{Nal}^{\mathrm{R}} \mathrm{Mop}(+)\right)$. A281: $(+)$ pTiBo542 (T-DNA(+) HP1838 (A281, right)) Agrobacterium strains. (Photo: Ahmed Nour El-Deen) 


\section{Table 3(on next page)}

Anti-Gram-positive and anti-Gram-negative fractions peptide-fractions obtained from EMA_PF2 by HPLC.

The antimicrobial active fractions could be collected between the 40 - 50 min period of HPLC

run. The Gram-negative and Gram-positive fractions could not be separated. For more details, see the Caption 
2 Table 3 Anti-Gram Positive and Anti-Gram-Negative Activities of HPLC (EMA_PF2) isolated 3 from the Cell-Free Culture Medium (CFCM) of Xenorhabdus budapestensis (EMA) by 4 Amberlite XAD1148® Adsorption, Methanol Elution, and Ultrafiltration in liquid culture 5 bioassay

6

\begin{tabular}{|c|c|c|}
\hline & \multicolumn{2}{|c|}{ OD Values at $600 \mathrm{~nm}$ for the fractions collected between $40-50 \mathrm{~min}$} \\
& \multicolumn{2}{|c|}{ (Mean $\pm \mathrm{SD}, \mathrm{n}=2$ at each time) } \\
\hline HPLC run & Staphylococcus aureus JE & \multicolumn{1}{c|}{ Escherichia coli HGB2226 } \\
\hline & & \\
\hline 1. & $0.3577 \pm 0.0797$ & $0.5380 \pm 0.009$ \\
\hline 2. & $0.4404 \pm 0.0511$ & $0.4214 \pm 0.0002$ \\
\hline 3. & $0.4273 \pm 0.0377$ & $0.4335 \pm 0.0002$ \\
\hline 4. & $0.4588 \pm 0.0307$ & $0.4625 \pm 0.001$ \\
\hline 5. & $0.4027 \pm 0.0285$ & $0.48135 \pm 0.00063$ \\
\hline 6. & $0.3874 \pm 0.0510$ & $0.4651 \pm 0.00198$ \\
\hline 7. & $0.4255 \pm 0.0571$ & $0.4395 \pm 0.0004$ \\
\hline 8. & $0.0003 \pm 0.0247$ & $0.00155000 \pm 0.0006$ \\
\hline 9. & $0.0003 \pm 0.0201$ & $0.00020000 \pm 0.0002$ \\
\hline 10. & $0.0081 \pm 0.0547$ & $0.001 \pm 0.0001$ \\
\hline 11. & $0.0040 \pm 0.0061$ & $0.0015 \pm 0.0002$ \\
\hline
\end{tabular}

7 
9 Captive / Footnotes to Table 3: Table 3 Anti-Gram Positive and Anti-Gram-Negative 10 Activities of HPLC (EMA_PF2) isolated from the Cell-Free Culture Medium (CFCM)

11 of Xenorhabdus budapestensis (EMA) by Amberlite XAD1148® Adsorption, Methanol Elution, 12 and Ultrafiltration in liquid culture bioassay

13 Anti-Gram Positive and Anti-Gram-Negative activities of HPLC Fractions from EMA_PF2

Abbreviations:

\section{HPLC Sample: af3; Peak: A2}

Fractions collected (from below A2, between 40 - 47 min exerted complete cytotoxic activities on both the Gram-positive and the Gram-negative test organisms. Fractions collected before and after this time-interval were completely inactive. Each mean was calculated from 3 replicates. In repeated experiments, using in different columns got similar results. (We were not interested in the growth rates of the bacterial cultures; only in the completely toxic fractions. This explains the layaways from the original protocol). 
Figure 7 (on next page)

OD values measured at different concentration of EMA_PF2 in liquid bioassays in the $L_{\text {, }}$ L,-succinamopine, AGR) catabolizing Agrobacterium strains

OD values (mean +/- SE; $\mathrm{N}=3$ ) measured in 0, 30, 45, 60 and 75 microgram/ml of EMA_PF2 in strain (A) A281 (HP1838); (B) AGL1 (HP1839); (C) EHA 105; (D) A4T. For genotypes and more details, see Captive to Fig 7). 
Results of in vitro liquid bioassays of EMA_PF2 agropine-catabolizing (AGR) Agrobacterium tumefaciens strains.
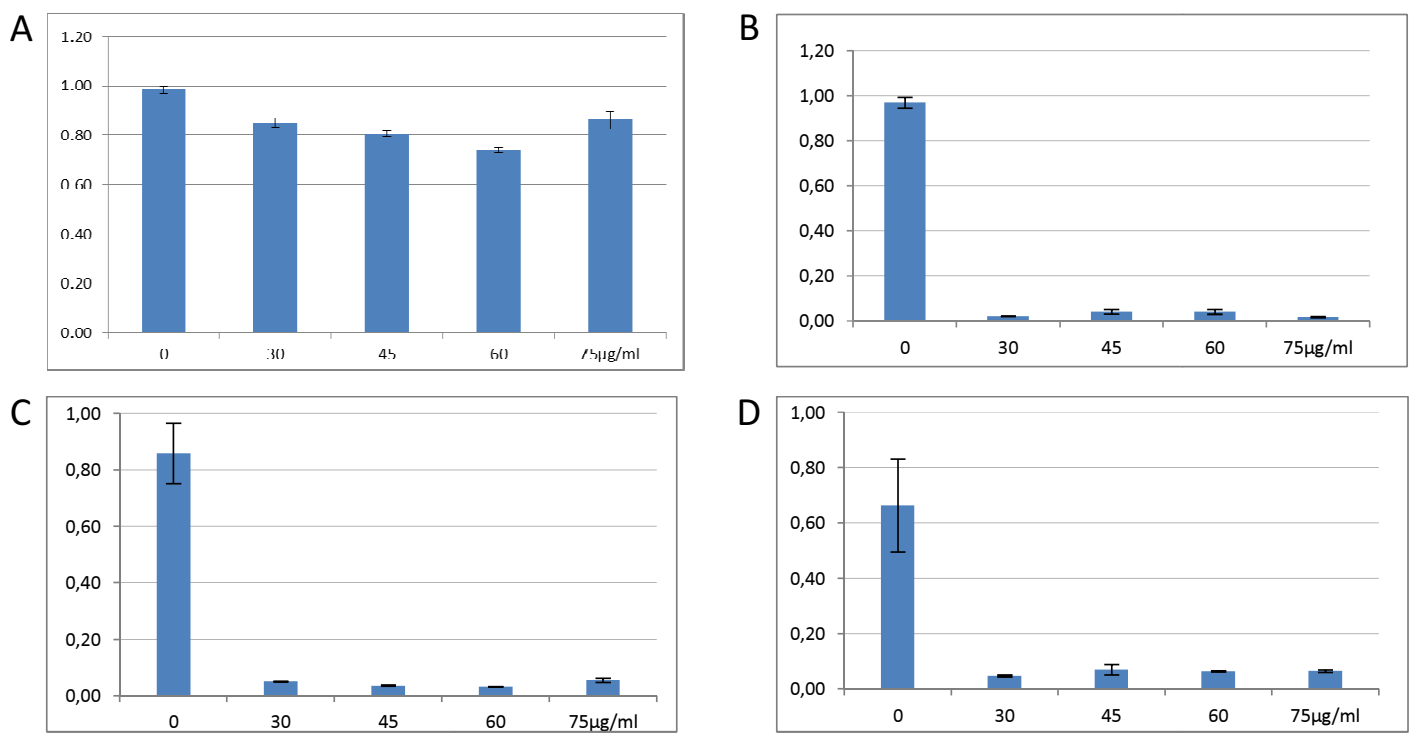

A: on wild-type A281 (HP1838) Genotype: C58 pTiA136Bo542 - TDNA (+) Rif ${ }^{\mathrm{R}}$; B: AGL1 (HP1839). Genotype: C58 (AG0) (RecA::bla) pTiA136Bo542 - TDNA (-) Rif® Ca® Nal® Mop (+). C: Fig 7C EHA105 (SZL1). Genotype: C58 pTiA136Bo542 DTDNA (-) / pBIN-19-(Intron)-Gus-Km® Rif® Nal® Mop (+) Km®; D:A4TC (SZL3). Genotype: C58 A4TC/pBIN-19 - (Intron-Gus-Km(R) Abscissa: EMA_PF2 dose $\mu \mathrm{g} / \mathrm{ml}$. Ordinate: OD values. 